NASA/TM-2005-213836

\title{
Current Experimental Basis for Modeling Ice Accretions on Swept Wings
}

Mario Vargas

Glenn Research Center, Cleveland, Ohio 
Since its founding, NASA has been dedicated to the advancement of aeronautics and space science. The NASA Scientific and Technical Information (STI) Program Office plays a key part in helping NASA maintain this important role.

The NASA STI Program Office is operated by Langley Research Center, the Lead Center for NASA's scientific and technical information. The NASA STI Program Office provides access to the NASA STI Database, the largest collection of aeronautical and space science STI in the world. The Program Office is also NASA's institutional mechanism for disseminating the results of its research and development activities. These results are published by NASA in the NASA STI Report Series, which includes the following report types:

- $\quad$ TECHNICAL PUBLICATION. Reports of completed research or a major significant phase of research that present the results of NASA programs and include extensive data or theoretical analysis. Includes compilations of significant scientific and technical data and information deemed to be of continuing reference value. NASA's counterpart of peerreviewed formal professional papers but has less stringent limitations on manuscript length and extent of graphic presentations.

- TECHNICAL MEMORANDUM. Scientific and technical findings that are preliminary or of specialized interest, e.g., quick release reports, working papers, and bibliographies that contain minimal annotation. Does not contain extensive analysis.

- CONTRACTOR REPORT. Scientific and technical findings by NASA-sponsored contractors and grantees.
- CONFERENCE PUBLICATION. Collected papers from scientific and technical conferences, symposia, seminars, or other meetings sponsored or cosponsored by NASA.

- SPECIAL PUBLICATION. Scientific, technical, or historical information from NASA programs, projects, and missions, often concerned with subjects having substantial public interest.

- TECHNICAL TRANSLATION. Englishlanguage translations of foreign scientific and technical material pertinent to NASA's mission.

Specialized services that complement the STI Program Office's diverse offerings include creating custom thesauri, building customized databases, organizing and publishing research results ... even providing videos.

For more information about the NASA STI Program Office, see the following:

- Access the NASA STI Program Home Page at http://www.sti.nasa.gov

- E-mail your question via the Internet to help@sti.nasa.gov

- Fax your question to the NASA Access Help Desk at 301-621-0134

- Telephone the NASA Access Help Desk at 301-621-0390

- Write to:

NASA Access Help Desk

NASA Center for AeroSpace Information 7121 Standard Drive

Hanover, MD 21076 
NASA/TM-2005-213836

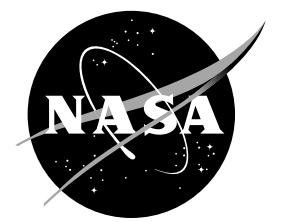

\section{Current Experimental Basis for Modeling Ice Accretions on Swept Wings}

\section{Mario Vargas}

Glenn Research Center, Cleveland, Ohio

Prepared for the

Fourth Theoretical Fluid Mechanics Meeting sponsored by the American Institute of Aeronautics and Astronautics Toronto, Ontario, Canada, June 6-9, 2005

National Aeronautics and

Space Administration

Glenn Research Center 


\section{Acknowledgments}

The author would like to thank Alric Rothmayer and Thomas Bond for suggesting a review paper on ice accretions on swept wings, and James Riley for his help with the bibliography.

Available from

NASA Center for Aerospace Information 7121 Standard Drive

Hanover, MD 21076
National Technical Information Service 5285 Port Royal Road Springfield, VA 22100

Available electronically at http:/ /gltrs.grc.nasa.gov 


\title{
Current Experimental Basis for Modeling Ice Accretions on Swept Wings
}

\author{
Mario Vargas \\ National Aeronautics and Space Administration \\ Glenn Research Center \\ Cleveland, Ohio 44135
}

\begin{abstract}
This work presents a review of the experimental basis for modeling ice accretions on swept wings. Experimental work related to ice accretion physics on swept wings conducted between 1954 and 2004 is reviewed. Proposed models or explanations of scallop formations are singled out and discussed. Special emphasis is placed on reviewing the work done to determine the basic macroscopic mechanisms of scallop formation. The role of feather growth and its connection to scallop growth is discussed. Conceptual steps in modeling scallop formations are presented. Research elements needed for modeling are discussed.
\end{abstract}

\section{Nomenclature}

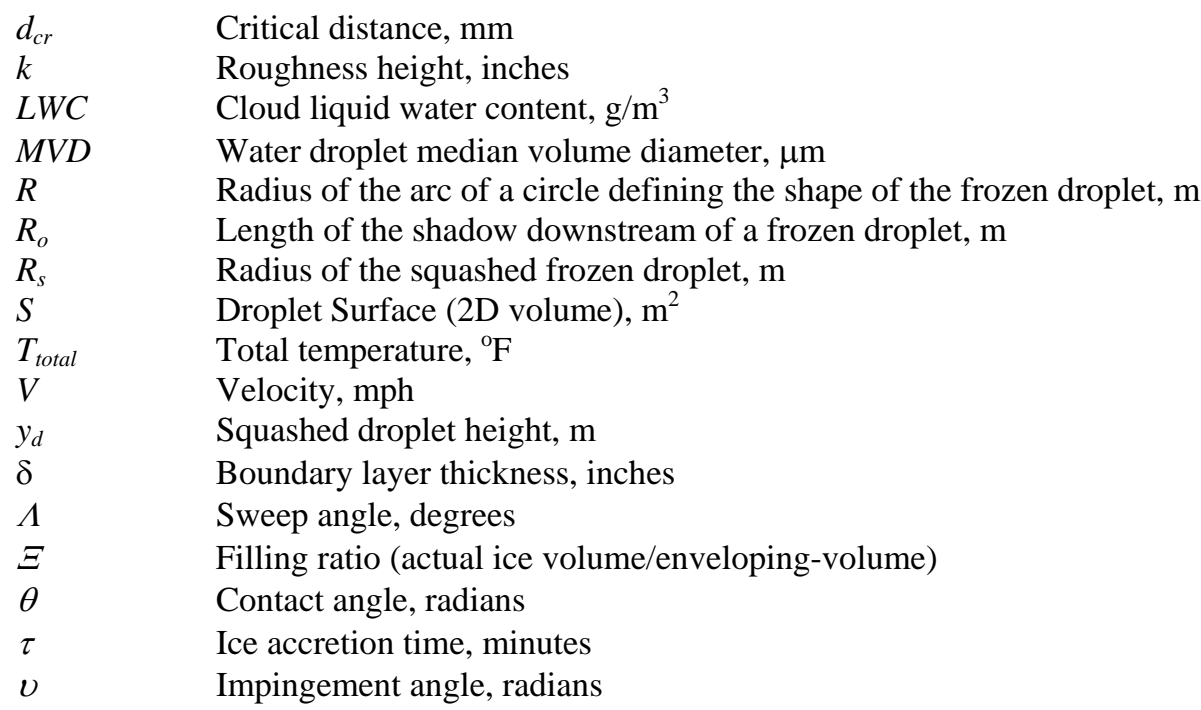

\section{Introduction}

An understanding of ice accretion formation on swept wings is a critical step in the development of ice accretion models that can be implemented into 3D ice accretion codes. In the rime ice regime, ice accretions at different sweep angles are not fundamentally different in their characteristics. In the glaze ice regime, as the sweep angle of an airfoil is increased from $0^{\circ}$, the ice accretion shows different characteristics. At high sweep angles, the ice accretion shows a type of formations not observed on unswept airfoils. These formations have been described as "cups", "scallops", or "lobster tails" and give a discontinuous look to the ice shape. The appearance of these characteristic formations adds complexity to ice accretions on swept wings and constitutes the main challenge in their modeling. 
The first explanation of scallop formation was suggested in 1954 and the first model was proposed in 1993, but it was not until 1998 that a systematic study was conducted to try to understand the mechanisms of formation. The renewed interest was lead by the development of LEWICE 3D. To be able to model ice accretions in LEWICE 3D it is critical to understand scallop formation. The work in the 90s determined how scallops form, identified critical parameters involved, clarified the connection between feather growth and scallop structures, and brought into focus the role of roughness heat transfer. Although more experimental research work remains to be done, especially in the area of roughness heat transfer effects, enough understanding of the formation of scallops has been gained to allow continuing steps towards modeling ice accretions on swept wings.

This report reviews the experimental work done from 1954 to 2004 on the formation of ice accretions on swept wings. No attempt was done to review the computational work during this period, but in several instances analytical and computational work will be mentioned as it relates to the experimental work.

The objective of the present work is to provide experimental, analytical and computational icing researchers a review of our current experimental understanding of ice accretion formation on swept wings, to what extent that knowledge can be used for modeling, the gaps in our knowledge, current research trends, and what research lies ahead.

\section{Initial Observations about Ice Accretions on Swept Wings}

The first observations on the differences between ice accretions on swept airfoils and ice accretions on unswept airfoils were published in 1954 by Von Glahn and Gray ${ }^{1}$. They reported that at glaze ice conditions, for an unswept NACA 63A-009, the ice accretion was a "continuous solid spanwise projection" (Fig. 1). For the same airfoil swept at $36^{\circ}$ and $60^{\circ}$, they observed "a broken spanwise formation resembling a row of nested cups formed". The photographic data that they presented show the scallop formations (Figs. 2 and 3).

They suggested the first explanation of scallop formation: "It is believed that as these rough glaze-ice deposits increase in size, local high spots are formed at intervals along the span because of a delay in the freezing of impinging water and a tendency to flow before solidification. These high points in the ice formation intercept more of the impinging water because of an increased local water-collection efficiency, and, as a result, adjacent ice deposits are shielded. The extent of shielding appears to be a function of the air-flow component parallel to the span as influenced by the sweep angle. A large sweep angle causes the shielding effect to extend farther along the span; hence, a greater separation is observed between the cups". Their explanation of scallop formation is based on water flowing on the surface and accumulating and freezing at certain spots. Our current understanding of scallop formation based on observations done in the 90s indicates that feather growth from roughness elements is the mechanism of scallop initiation.

In 1955 Bowden $^{2}$ mentioned the presence of cup-shaped ice formations at glaze ice conditions, on a delta wing (tip section) having a NACA 0004-65 airfoil section and a $60^{\circ}$ leading edge sweepback. He showed photographic data of the scallops.

In 1959 Rusch $^{3}$ studied ice accretions formed on a delta wing of unity aspect ratio having leading edge separation. He did not directly describe the scallops but in the photographic data that he presented scallop formations can be seen.

In 1969 Boeing conducted an experiment in the Lewis Icing Research tunnel aimed at developing an empirical correlation to predict the ice accretions formed on a BAC-450 and a BAC-470 airfoil ${ }^{4,5}$. The BAC 450 was representative of an inboard section. It had a $27.5^{\circ}$ leading edge sweep angle. The BAC 470 was representative of an outboard wing and horizontal stabilizer sections. It had a $40^{\circ}$ leading edge sweep angle.

As part of the experiment, ice shape tracings, plaster castings and photographic data of the ice accretions were obtained for a range of icing conditions. Several observations were made about the formation of ice accretions on swept wings at glaze ice conditions. They observed that the effect of wing sweepback on the ice accretion was the presence of "discontinuous cup shapes formed in the spanwise direction". 
Their photographic data show the cup shaped ice formations (Fig. 4). They observed that the separation between the scallops is larger in the glaze ice formations than in mixed ice accretions. They also observed that when the ice accretions were thicker than 1.5 inches there was a reduction in the growth. They observed that ice accretions with a thickness less than 2 inches had a different structure of build-up than ice accretions with thicknesses greater than 2 inches.

In September of 1977, the Fluid Dynamics Panel of the Advisory Group for Aerospace Research and Development (AGARD) held a Round-Table Discussion in Ottawa, Canada, on the Fluid Dynamics aspects of Icing. The papers presented at the meeting constitute a state-of-the-art survey of a broad spectrum of icing topics, and were published in the AGARD Advisory Report No.127. At the AGARD meeting Wilder ${ }^{6}$ presented a paper that discussed the experimental determination of ice shapes using the ice shape correlations reported by Blair ${ }^{4}$ and Shah ${ }^{5}$. He clearly outlines the methodology followed, main parameters, and gives a numerical example of the application of the ice shape correlations. He also discusses calculation procedures and adds some comments on wind tunnel testing evaluation of the effects of ice on airplane performance and stability, and comments on flight testing with simulated ice shapes. In relation to Ice Accretion Physics, he presents photographic data of glaze ice shapes (scallops) and pictures of castings obtained from glaze ice shapes. He also reports (in reference to scallop formations) that "the separations were more prominent in the glaze ice formations and became larger as the ice thickness increased. In those samples which tended toward rime ice, the distance between individual cups decreased and in some cases formed a continuous solid ice cap along the span of the airfoil". This observation was confirmed in the experiments conducted in the 90 s.

Several other papers presented at the AGARD Fluid Dynamics Panel Round-Table Discussion on Aircraft held in Ottawa mention scallop formations. Laschka and Jesse ${ }^{7}$ have a short comment on the presence of scallops in swept wings. Pierre and Vaucheret ${ }^{8}$ present pictures of scallop formations and of plaster ice cape replicas. Armand, Charpin, Fasso and Leclere ${ }^{9}$ present photographic data of scallop formations on a delta wing, for a reference case and for the same delta wing at 1/6 scale. They also show photographs of scallops formed on a 1/12 scale model of an Airbus wing and the corresponding casting for the actual ice scallop formation from the flight test.

In the winter of 1989-90 Reehorst ${ }^{10}$ conducted an experiment in the NASA Glenn Research Center's DHC-6 DeHavilland Twin Otter aircraft to obtain swept wing ice accretion data. Research flights were made into icing conditions. A NACA 0012 swept wing tip airfoil was extended from the overhead hatch of the aircraft and set at a given sweep angle $\left(0^{\circ}, 30^{\circ}\right.$, or $\left.45^{\circ}\right)$ for a given duration of the icing encounter. At the end of the icing encounter the airfoil was retracted into the cabin of the aircraft and photographic data and ice shape tracings were taken. Icing cloud environment and aircraft flight data were measured and recorded. From the icing conditions and the types of ice accretions that he reports, the strong effect of sweep angle and temperature on the formation of the scallops can be inferred.

The NASA LEWICE 3D code (1991 version) was used to predict ice accretion profiles for five of the flight test runs. The code results were compared to the ice shape tracings from the in-flight icing data. Because LEWICE 3D did not have a model of scallop formation, the code predictions did not match the experimental data. The code consisted of a three dimensional Hess-Smith panel code, a three dimensional particle trajectory code, and the two dimensional LEWICE 2D code. LEWICE 2D was applied along surface streamlines calculated by the 3D panel code to obtain the ice accretion prediction. To improve the situation, the roughness parameter (in the LEWICE 2D module) and the value of the density were adjusted arbitrarily to obtain better agreement. The results showed the code's limitations at the time, and the need to have a scallop model in LEWICE 3D.

In 1992 Hansman et al. ${ }^{11}$ conducted a close-up video analysis of ice accretion on a faired 3.5 inch diameter metal-clad cylinder and a 2 inch aluminum cylinder. Although the main observations in the test were related to horn formation in 2D ice accretions on unswept wings, observations on feather initiation and growth were also reported. Those observations are important in the modeling of ice accretions on swept wings. They observed that feather initiation can be traced to an original nucleation site. If the initial surface has irregularities these will be nucleation sites. If the initial surface is smooth, the natural ice surface roughness will grow until the local roughness elements are sufficient to provide nucleation sites for feather growth. They observed that feather growth was not limited to rime ice accretions (rime feathers). Feathers were also observed to grow out of clear glaze ice (glaze ice feathers). They also observed that since feathers tended to spread out laterally, when the feather density is high, adjacent feathers will tend to merge. Reehorst et al. ${ }^{12}$ used the same experimental setup for close-up in-flight observations in 
the NASA Glenn Research Center's Twin Otter Icing Research Aircraft. They measured the effect of droplet size and water flux on the feather growth rate.

\section{First Model of Scallop Formation}

In 1993 Hedde and Guffond ${ }^{13}$ reported on improvements to the ONERA 3D icing code. They compared the code predictions to experimental shapes obtained on a NACA 0012 airfoil from an experiment by Reehorst ${ }^{10}$. For the unswept case the code predictions agreed well with the experimental data. For the swept case, where the experimental shapes exhibited scallop formations, the code predicted smaller shapes. They realized that they had reached the limits of the 3D icing code because of the presence of scallop formations. They proposed a model of scallop formation with two steps (Fig. 5): the initiation and the macroscopic growth.

Initiation is modeled by assuming that scallops begin to form because of the presence of two processes: (1) individual droplets arriving at the surface freeze before being impacted by other droplets, and (2) the impingement angle of the other arriving droplets combined with the height of the frozen droplet on the surface, create a zone of high collection efficiency probability at the location of the surface droplet, and an area of zero collection efficiency probability behind the surface droplets (shadow region). This part of the model explains the scallop initiation and the discontinuity or spacing present in the ice accretion.

Macroscopic growth is modeled by assuming that the impingement angle of the droplets determines two distinct areas of heat transfer on the scallop: a zone of high heat transfer coefficient where the incoming droplets freeze on impact, and a zone of lower heat transfer coefficient on the sides of the scallops where the droplets do not freeze on impact and form a water film before freezing.

They applied their conceptual two-step model of scallop growth to develop a 2D Ballistic model of scallop growth (Fig. 6). Three parameters are input in this 2D model: the surface area $S$ of a droplet before impinging and freezing; the impingement angle $v$, and the contact angle $\theta$. They assumed that the shape of the frozen droplet has a contact angle $\theta$, and is a sector of a circle of radius $R$ determined by $S$ and $\theta$, and that the area of the frozen droplet is the same as it was before impacting and freezing. This allows calculation of the circle radius $R$, the droplet spreading radius $R_{s}$, the length of the shadow region downstream of a frozen droplet $R_{o}$, and the height of the droplet $y_{d}$ (Fig. 7).

The growth of the 2D ice accretion is obtained by considering where a droplet hits with respect to the ice accretion (Fig. 8). If it hits on the wall or at the top of the ice hummock it freezes individually and the new drop height $y_{d}$ is added to the wall or the ice already there. If the drop impinges on the flank, then a film freezing case is assumed and the height of the droplet is added to the mean ice height over the droplet spreading length $2 R_{s}$.

They presented results for the 2D ballistic model (Fig. 9) to show that at low impingement angle, discontinuities will appear on the ice formation. They plotted the filling ratio $\Xi$ (actual ice volume/enveloping-volume), against the angle of impingement for a range of contact angles, and used the results for $\Xi=0.9$ to define a criteria for scallop initiation, while pointing out that another criterion on heat transfer was needed to completely define the conditions for lobster tail growth.

The two step conceptual approach dividing scallop growth into initiation and macroscopic growth remains a valid approach. However, their actual modeling of each step will need to be modified because later observations of ice accretion on swept wings do not support the details. Their initiation of scallop growth based on individual droplets hitting the surface and freezing is not supported by our current understanding of the initiation of glaze ice formation. Observations by Olsen and Walker ${ }^{14}$ indicate that in the initial stages of the glaze ice formation, impinging droplets hit the surface without freezing and coalesce to form larger droplets, the largest of the order of 300 microns in diameter. Large droplets are moved downstream by the wind forces, while new droplets are being formed and grow with the impinging droplets. After a few seconds of this process the motion of all the droplets on the surface stops and the ice accretion process really begins. Movies taken of the ice accretion process show that large liquid droplets remain on the ice surface during glaze ice formation, with their shapes continually being deformed by the action of the flowing air. Experimental observations done in the 90s indicate that the freezing of these large droplets are the initiation of the scallops ${ }^{15,16}$. 
In the Hedde-Guffond model, the spacing (“discontinuities”) of the scallops is modeled in the initiation process by the shadowing created by the frozen droplets on the surface and the impingement angle of the incoming droplets. This part of their model is not supported by recent observations of scallop formation ${ }^{15,16}$.

The model for macroscopic growth proposed by Hedde and Guffond is based on differences between the heat transfer at the top of the scallops, and the heat transfer on the side of the scallops. On the area of high heat transfer the droplets are assumed to freeze on impact. Recent observations of castings of scallop growth ${ }^{15,16}$ indicate that scallops are made of feathers, and feather growth is different for glaze ice feathers than rime ice feathers. Glaze ice feathers show typical glaze ice formation on their top surface. So the macroscopic growth model of Hedde-Guffond won't apply to them. Rime ice feathers show a whitish color that indicates they are formed by droplets freezing on impact. In this case, part of the Hedde-Guffond macroscopic growth model may apply.

Hedde and Guffond's model of scallop growth is the only one attempted so far. Their two step conceptual approach, with modifications introduced by recent observations on scallop formation ${ }^{15,16}$, may be the starting point for modeling scallops in the future.

\section{Swept Wing Icing Physics Studies at NASA Glenn Research Center}

From 1996 to 2004 the Icing Branch at the NASA Glenn Research Center conducted a detailed research program on ice accretion formation on swept wings. Several experiments were conducted to study different aspects and parameters related to ice accretion formation, with focus on scallop formation.

\section{A. Study on Mechanisms of Scallop Formation}

In 1996 Vargas and Reshotko ${ }^{15,16}$ conducted a series of experiments in the Icing Research Tunnel (IRT) to understand the physical mechanisms that lead to the formation of scallops on swept wings. Icing runs were performed on a NACA 0012 swept wing tip (Fig. 10) at $45^{\circ}, 30^{\circ}$, and $15^{\circ}$ sweep angles starting with a baseline case at $45^{\circ}$. The time history of scallop formation was studied for the baseline case. Direct measurements of scallop height and spacing, castings (Fig. 11), video data and close-up microphotography data were obtained. For comparison with the baseline case, tests were run at sweep angles of $30^{\circ}$ and $15^{\circ}$ with the other conditions the same as the base case, for ice accretion times of 2, 5, 8 and 10 minutes. For the $15^{\circ}$ sweep angle, a special case of scallop formation on the end cap of the airfoil was studied. Additional icing runs were carried out to study the velocity effect, the temperature effect and the LWC effect on the formation of the scallops. Measurements of scallop height and spacing versus ice accretion time were performed. Measurements of the distance from the attachment line to the point beyond which the roughness elements become glaze ice feathers were taken at several conditions.

The experiments in 1996 showed that:

1. Scallop formation is governed by local effects on roughness elements.

2. Scallops can be classified as complete scallops, incomplete scallops and no-scallops (Figs. 12, 13 and 14).

3. Scallops are made of glaze ice feathers that grow from roughness elements located beyond a given distance from the attachment line. This distance is called the critical distance, $d_{c r}$ (Fig. 15). It is a critical parameter in the formation of scallops, it determines (together with the shape of the streamlines) if complete scallops, incomplete scallops or no-scallops are going to be formed.

4. The feathers that form the scallops show a preferred direction of growth perpendicular to the streamlines (Fig. 16).

5. When the critical distance is zero, all the ice shape is covered with glaze ice feathers and if the shape of the streamlines is such that the preferred direction of growth of the feathers is conducive to formation of scallop tips, complete scallops form (Figs. 12 and 17). During complete scallop growth, feathers join along the preferred direction of growth to form ridges. The ridges grow to form scallop tips. The feathers along the attachment line join with other feathers to form areas of solid ice. The scallop tips grow in size by joining with other scallop tips at the top of the feathers that form them, and in this way the separation between the scallop tips is increased (scallop spacing, defined as the number of scallops per unit length, is decreased).

6. When the critical distance is different from zero, two zones appear: the attachment line zone and the glaze ice feathers zone. The preferred direction of growth of the feathers in the glaze ice feathers zone depends on their 
distance from the attachment line proper since the preferred direction of growth of the feathers is perpendicular to the streamlines and the shape of the streamlines for a given airfoil geometry depend on the distance from the attachment line proper. If the preferred direction of growth of the feathers of the glaze ice feathers zone is aligned too closely with the attachment line direction, the feathers will form ridges but the ridges will not form scallop tips. In this case, no-scallops are formed (Figs. 14 and 18). If the preferred direction of growth is not aligned too closely with the attachment line direction, then the feathers will form ridges and the ridges will grow to form scallop tips, and the scallop tips will show the same mechanism of growth observed when studying complete scallops. Since only the scallop tips are formed, we call this kind of ice accretion an incomplete scallop (Figs. 13 and 19).

7. When the attachment line zone and the glaze ice feathers zone appear, which zone prevails depends on the conditions. When the attachment line zone dominates, the ice of the attachment line will eventually cover the glaze ice feathers zone. In the case of incomplete scallops, the feathers may form scallop tips before they are covered. When the glaze ice feathers zone prevails the scallop tips grow in size and dominate the ice accretion.

8. When the critical distance is large, the glaze ice feathers zone is very small, and the ice of the attachment line zone completely dominates the ice accretion and creates a characteristic ice shape. This ice shape is always observed when the sweep angle or the tunnel conditions create a large value of the critical distance.

9. The critical distance was measured against the sweep angle and tunnel parameters. It was found to increase as temperature or LWC are increased, and to decrease as the sweep angle is increased.

10. Velocity, temperature, and LWC influence the formation of the scallops by affecting the critical distance, the growth of the ice in the attachment line zone, and the growth of the feathers in the glaze ice feathers zone.

11. Observations of ice accretions on the end cap of the airfoil showed that for the same tunnel conditions the scallops showed a very strong dependence on local sweep angle.

12. Scallop height was found to increase linearly with ice accretion time.

13. Scallop spacing, defined as the number of scallops per unit length, was found to decrease with ice accretion time.

14. For glaze ice accretions on swept wings, four elements determine the type of the ice accretion shape: the critical distance $d_{c r}$, the shape of the streamlines for the particular airfoil geometry at a given sweep angle, the rate of feather growth, and the rate of attachment line growth.

15. The physical mechanisms that make roughness elements located beyond the critical distance to grow into glaze ice feathers are not known. The strong dependence of scallops on local sweep angle suggests that the cross flow instability must be considered as one of the candidate physical mechanisms, and further research should be done to establish if it plays a role in the growth of the roughness elements into glaze ice feathers.

16. The video data showed that in all cases the beginning of the glaze ice accretion process was similar to what has been reported ${ }^{14}$ for the $2 \mathrm{D}$ case: the small supercooled incoming water droplets impinge on the surface of the airfoil and form droplets that are moved downstream by wind forces, then the drops stop moving and the ice accretion begins to form.

17. Time history photographic data of scallop formation at a base case $\left(45^{\circ}\right.$ sweep angle, $150 \mathrm{mph}, 25^{\circ} \mathrm{F}, 0.75 \mathrm{~g} / \mathrm{m}^{3}$ LWC and $20 \mu \mathrm{m}$ MVD for ice accretion times of 0.5, 1, 2, 3, 4, 5, 6, 7, 8, 9, 10 and 12 minutes) indicated that up to 1 minute the ice accretion is covered with roughness elements (Fig. 20). The actual growth of the roughness elements into feathers occurs between 1 and 2 minutes (Fig. 21). The photographic data for the base case indicated that the roughness elements need to reach a certain size (about $1 \mathrm{~mm}$ in the base case) before they start growing into feathers. Because the photographic data was taken at 30 seconds and 1 minute intervals, the observations were "snapshots of the process" and not all the process was observed. From the photographic data it was clear that between 1 minute and 2 minutes into the ice accretion formation the ice accretion area transitions from being covered with roughness elements to being covered with glaze ice feathers that grow from the roughness elements. It was not possible to determine if the growth of the roughness elements into feathers occurs uniformly or if it starts at a location and propagates to all the ice accretion.

\section{B. Implications for Icing from 1996 Results}

The observation that the scallops are made of glaze ice feathers that grow from roughness elements located beyond a given distance from the attachment line has important consequences for icing because it connects scallop 
formation with local effects on 3D roughness elements. The critical parameter in scallop formation is the critical distance, $d_{c r}$. It determines (together with the streamlines shape) if complete scallops, incomplete scallops, or noscallops are going to be formed. If the mechanisms that trigger the growth of the roughness elements into glaze ice feathers can be identified and studied, it will allow incorporation of a parameter or parameters into the 3D ice accretions codes that will allow the codes to predict the critical distance and consequently whether scallops are going to form, and if so which type. In order to identify the physical mechanisms that are causing the roughness elements to develop into glaze ice feathers, further research is needed into the effect of roughness elements (of the sizes encountered in the formation of the scallops) on the 3D boundary layer, and on boundary layer instabilities. Studies of flow field and heat transfer are needed.

\section{Study on Effect of Velocity and Sweep Angle on the Critical Distance}

In 1998 a parametric experimental study on the effect of velocity and sweep angle on the critical distance ${ }^{17}$ was conducted on a swept NACA 0012 wing tip airfoil. At each condition the sweep angle was changed from $0^{\circ}$ to $45^{\circ}$ at $5^{\circ}$ increments. The results showed that at a given velocity and tunnel conditions, as the sweep angle was increased from $0^{\circ}$ to $25^{\circ}$, the critical distance slowly decreased and overall the ice accretions remained similar to the $0^{\circ}$ sweep angle case. As the sweep angle was increased past $25^{\circ}$, the critical distance started decreasing rapidly until it reached a value of 0 millimeters (Fig. 22). On the ice accretion as the sweep angle was increased above $25^{\circ}$, the extent of the attachment line zone decreased rapidly and incomplete scallops formed. When the critical distance reached 0 millimeters complete scallops formed. The critical distance decreased to 0 millimeters at $35^{\circ}$ sweep angle for 75 and $100 \mathrm{mph}$ and at $40^{\circ}$ sweep angle for 150 and $200 \mathrm{mph}$.

\section{Study on Effect of Temperature and LWC on the Critical Distance}

In 1998 a study on the effect of LWC and temperature on the critical distance ${ }^{18}$ was conducted on a swept NACA 0012 wing tip airfoil. At each condition the sweep angle was changed from $0^{\circ}$ to $45^{\circ}$ at $5^{\circ}$ increments. The results indicated that decreasing the LWC or the total temperature decreased the value of the critical distance at a given sweep angle compared to a baseline case (Figs. 23, 24) and started the formation of complete scallops at an earlier sweep angle. Increasing the LWC increased the value of the critical distance (compared to the baseline case) for sweep angles between $30^{\circ}$ and $45^{\circ}$. The critical distance value remained greater than 0 millimeters and complete scallops were not formed for all values of the sweep angle up to $45^{\circ}$. When the total temperature was increased to $30{ }^{\circ} \mathrm{F}$, bumps covered with roughness elements appeared on the ice accretion at $25^{\circ}$ and $30^{\circ}$ sweep angles, large ice structures appeared at $35^{\circ}$ and $40^{\circ}$ sweep angles, and complete scallops were formed at $45^{\circ}$ sweep angle.

\section{E. Study of Scallop Formation in Natural Icing Conditions}

In the winter of 2000-2001 an experiment was conducted in the DeHavilland DHC-6 Twin Otter Icing Research Aircraft at NASA Glenn Research Center to study the formation of ice accretions on swept wings in natural icing conditions $^{19}$. The experiment was designed to obtain ice accretion data to determine if the mechanisms of ice accretion formation observed in the Icing Research Tunnel were present in natural icing conditions. The experiment in the Twin Otter was conducted using the same NACA 0012 swept wing tip used in the 1996 and 1998 experiments in the IRT. The model enabled data acquisition at $0^{\circ}, 15^{\circ}, 25^{\circ}, 30^{\circ}$, and $45^{\circ}$ sweep angles. Casting data, ice shape tracings, and close-up photographic data were obtained. The results showed that the mechanisms of ice accretion formation observed in-flight agree well with the ones observed in the Icing Research Tunnel.

\section{F. FAA/NASA/WSU Study of Aerodynamic Effects of 3D Ice Accretions}

In 2001 the Federal Aviation Administration, NASA and Wichita State University ${ }^{20}$ conducted a study of the aerodynamic effects of 3D ice accretions. The objective of the research program was to develop an experimental database of ice accretions effects on the aerodynamic performance of finite swept wings. The data from the program was expected to help regulatory authorities in determining compliance issues.

A $28^{\circ}$ swept GLC-305 airfoil was designed and fabricated. It was a 5-ft semispan finite wing reflection plane model. It was equipped with an aileron control surface. The airfoil was designed with three removable leading edges (that covered the full span of the airfoil) to allow the making of molds to be used for the fabrication of ice shape castings used in the aerodynamic tests.

An icing test ${ }^{21}$ was conducted at the NASA Glenn Icing Research Tunnel facility to generate five glaze ice shapes with complete and incomplete scallop features, and one rime ice shape. The ice accretions times ranged from 
2 to 22.5 minutes. A mold of each ice accretion was obtained and castings were fabricated for the aerodynamic testing (Table 1).

3D simulated ice shapes were generated with NASA Glenn Research Center LEWICE v2.0 for the same icing conditions used in the IRT icing tests, and were fabricated from wood or aluminum. To create the computer generated ice shapes using a 2D ice accretion code a methodology ${ }^{22}$ was developed and comparisons were made between the LEWICE generated 3D ice shapes and actual ice shapes from the tunnel tests. For the aerodynamic testing the LEWICE generated ice shapes were tested clean and with roughness added.

A second experiment ${ }^{23,24}$ was conducted at the WSU 7 -ft $\mathrm{x} 10$-ft wind tunnel facility to generate the aerodynamic data for the clean and iced wing. Tests were performed with the IRT ice shapes and the LEWICE generated ice shapes at a Reynolds number (based on wing mean aerodynamic chord) of $1.8 \times 10^{6}$.

The aerodynamic tests showed that compared to the clean wing the IRT glaze ice shape castings decreased the stall lift coefficient by $11.5 \%$ to $93 \%$, and the rime ice shape increased it by $3.4 \%$. The IRT ice shape castings increased the minimum clean wing drag coefficient by $133 \%$ to $3533 \%$ and increased the drag near stall by $17 \%$ to 104\%. The aileron effectiveness was not affected by the ice shapes. The LEWICE generated ice shapes with roughness followed the same trend in aerodynamic performance degradation as the IRT ice shape castings but the losses were higher for the IRT ice shapes. The rough LEWICE shapes resulted in greater aerodynamic performance degradation than the smooth ones.

In the course of the aerodynamic testing a limited study was conducted on the effect of gaps between scallop tips. The ice shape casting for the 22 minutes complete scallop was used. The gaps between the scallops were progressively filled with a modeling compound to produce an ice shape with a "solid" horn. The aerodynamic data showed that the scallop features and in particular the gaps between the scallops can result in greater loss of lift than ice shapes with solid horns. It was a limited study and the authors stressed the danger of generalizing before more systematic studies are conducted, but if the results are confirmed by additional research studies it will have very important consequences for modeling scallops because it will indicate (from the aerodynamic perspective) how much detail has to be included in the actual modeling.

\section{G. Characteristics of the Ice that Forms Ice Accretions on Swept Wings}

From icing studies on swept and unswept airfoils conducted at NASA Glenn Research Center there has been no indication that the macroscopic characteristics of the ice that forms ice accretions and structures on swept wings are any different from those of the ice on unswept wings. Glaze ice feathers growing out of large roughness elements and with a preferred direction of growth perpendicular to the direction of the streamlines are observed on ice accretions on unswept wings (Fig. 25). Rime ice feathers are observed on ice accretions on swept and unswept airfoils (Fig. 26). Glaze ice covered with large roughness elements is also observed in both cases.

Scallop formations are three dimensional structures. The roughness elements that develop into feathers to form the scallops are also three dimensional structures. There are no 2D roughness elements in icing. Based on the observational experimental data and limited quantitative photographic data on distribution and diameters, single roughness elements seen on ice accretions on swept wings appear no different from single roughness elements seen on ice accretions on unswept wings.

\section{Conceptual Steps in the Modeling of Scallops}

Because scallop formations are macroscopic structures made out of icing feathers, we need to model feather growth to model scallops. The conceptual two-step model proposed by Hedde and Guffond ${ }^{13}$ remains a good starting point if we add the modifications introduced by our more recent knowledge of scallop formation. Like Hedde and Guffond, we can divide the modeling of the scallops into Initiation and Macroscopic Growth (Fig. 27).

The Initiation Step (Fig. 27a) involves modeling the formation and growth of large roughness elements, and their development into glaze or rime ice feathers under a given flow field and icing conditions. By "large roughness elements" we mean that the roughness element at a given location is of a height comparable or larger than the size of

the boundary layer at that location. An important part of the Initiation Step is to predict when large roughness elements are going to develop into feathers. The Initiation Step requires knowing the roughness characteristics 
(spacing, shape, time growth and size) under a given flow field and icing conditions, and modeling the effect of large roughness effects on flow field and heat transfer.

The Macroscopic Growth Step (Fig. 27b) involves modeling the growth of the feathers (individually or in groups of multiple feathers) after initiation. This step requires the ability to model the feathers' angle, the preferred shape of the feathers, the feathers' rate of growth, how the feathers align with respect to flow direction and streamlines, and how the feathers join and form additional structures. All these elements need to be modeled for glaze and rime ice feathers.

\section{Discussion of Research Elements needed for Modeling}

\section{A. Roughness Characterization for Ice Accretions on Swept Wings}

Studies of roughness characterization (size, distribution, time growth) for icing on unswept wings (2D Boundary layers) were conducted by $\mathrm{Shin}^{25}$ and Anderson ${ }^{26,27}$. No comparable data exists for large roughness elements on swept wings (3D Boundary Layer). Photographic data and measurements of roughness diameters ${ }^{15,16}$ exist for a few cases (Fig. 28). From this limited set of data, the diameters of roughness elements on glaze ice accretions on swept wings appear to be of the same order of magnitude as the diameters of roughness elements on ice accretions on unswept wings. Nevertheless, at this time there is not a complete set of data on roughness distribution, size, and time growth against icing parameters for ice accretions on swept wings.

\section{B. Glaze Ice Roughness Formation on Ice Accretions on Swept Wings}

In $2003 \mathrm{Tsao}^{28}$ examined the role of large scale cross flow on the formation of large roughness elements on the leading edge of a swept wing in glaze ice conditions. The physical model consisted of a substrate of ice covered by a thin water film and air flowing over the water. A fully three dimensional triple-deck structure was developed for the air 3D boundary layer flowing over the liquid film. The 3D triple-deck structure was an extension of the 2D triple-deck structure developed by Tsao and Rothmayer ${ }^{29,30,31}$ to investigate the air/liquid -water/ice/solid wall multi-phase flow instabilities as a mechanism for roughness formation on an unswept airfoil at glaze ice conditions. The main interaction between the air triple-deck structure, the film and the ice substrate was assumed to be through the lower deck. The governing equations, the boundary conditions, and the matching conditions at the interfaces were developed for the lower deck, the liquid film, and the ice. A linear stability analysis was conducted after reducing the $3 \mathrm{D}$ stability problem to an equivalent $2 \mathrm{D}$ stability problem, and then the quadratic dispersion relation for the linear instability eigenvalues was obtained.

To assess the cross flow effects, a parametric study was conducted starting from an experimental test condition for a wing section at $0^{\circ}$. He found out that when the cross flow is present the instabilities are enhanced and the most linearly unstable modes are strictly three-dimensional. To apply the stability analysis to an experimental case, a "quasi 3D" synthetic global flow was imposed. The "quasi 3D" consisted of a 2D boundary layer flow near the leading edge (along the chord wise direction), and a prescribed spanwise flow (velocity distributions). The stability analysis indicated that: (1) The leading edge region is covered entirely with three dimensional ice roughness elements of different sizes and aspect ratios; (2) A region of strong instability was centered some distance downstream from the attachment line. The roughness elements in this region are expected to grow faster and larger than roughness elements in other locations. The results agreed well with the experimental case. Tsao also found that for the physical model used there is a relationship between the Messinger freezing fraction and small scale ice roughness (feather) growth.

\section{The 3D Boundary Layer and Ice Accretions on Swept Airfoils}

Icing on swept wings introduces an added complexity: the boundary layer is now a 3D boundary layer. This brings into play boundary layer instabilities that are not present in 2D boundary layers.

In 1996 Vargas and Reshotko ${ }^{15,16}$ found that the critical distance was repeatable and fairly constant along the span of the airfoil. It suggested that after the roughness elements reach a certain size, a physical mechanism or a combination of physical mechanisms is causing some heat enhancement that triggers the roughness elements beyond a given distance from the attachment line to grow into small feathers. Vargas and Reshotko considered boundary layer instabilities as possible candidates for one of the physical mechanisms because the scallop formation showed a strong dependence on the sweep angle, complete scallops were present for the tunnel conditions where cross-flow 
vortices are expected to be stronger, and a wavelength separation at the base of the feathers (beginning of the growth of the roughness elements into feathers) was observed on the castings.

For a NACA 0012 airfoil swept wing used in the 1996 experiments three instabilities may be present in the laminar boundary layer ${ }^{32-36}$ : attachment line, streamwise, and crossflow instabilities. The instabilities may exist independently or simultaneously. Because the attachment line Reynolds number was less than 250 (Poll's criterion $^{36}$ ) the attachment line instability was not present. The streamwise instability is made of streamwise traveling waves, similar to the T-S waves in two-dimensional flows. Because the airfoil is suspended above the tunnel floor there was no leading edge contamination as in the case of a wing attached to a fuselage. Near the leading edge the negative pressure gradient for the NACA 0012 swept wing damps out the streamwise turbulence but creates a cross flow velocity that favors the crossflow instability. The crossflow instability appears in regions of strong pressure gradient on swept wings. The wing sweep and the pressure gradient curve the streamlines in the leading edge region, and in the boundary layer the presence of the wall lowers the momentum of the fluid and a velocity profile develops in a direction normal to the inviscid flow velocity. This flow is called a crossflow (Fig. 29). The crossflow velocity profile has a zero velocity at the wall and at the boundary layer edge, with an inflection point in between. The inflection point makes this velocity profile dynamically unstable and causes cross flow vortices. The direction of rotation of the vortices is in a plane normal to the streamline direction. For the NACA 0012 swept wing tip at the conditions of the 1996 experiment, the crossflow instability was the only instability that may be present near the leading edge where the ice accretion is formed.

In 1998 Reshotko, Vargas and Reed ${ }^{37,38}$ presented stability calculations for the onset and growth of stationary crossflow disturbances over an infinitely swept wing (NACA 0012 shape) at chord Reynolds numbers of $1.25 \times 10^{6}$ and $2.5 \times 10^{6}$ corresponding respectively to speeds of $100 \mathrm{mph}$ and $200 \mathrm{mph}$. The Branch I and Branch II locations for the stationary crossflow vortices that have the highest growth rates near the leading edge region were superimposed on plots of the critical distance (experimentally measured values) versus sweep angle. The sharp decrease in the critical distance with increasing sweep angle followed the trend of the Branch I curve. The growth rates of the crossflow disturbances were also superimposed on the critical distance plots. The rapid decrease of the critical distance beyond $25^{\circ}$ sweep angle occurred around the same sweep angles at which there was a rapid increase in growth rate. Any consideration of crossflow vortices or any other instability mechanism in icing should be understood that it refers to the initial stages of formation of the roughness and the ice accretion. Stability theory can comment only on the features of the initial ice formation.

The roughness elements observed and measured in the 1996 experiments ${ }^{15,16}$ were much larger than the typical roughness elements considered in boundary layer stability studies, and it is expected that they are of the order of magnitude of the boundary layer thickness or larger. The effect of roughness elements that size on the 3D boundary layer instabilities and transition is not known. At the present time no experimental work has been done in this area. The 1996 observations and the 1998 stability calculations indicate the need for experimental studies to determine if cross flow vortices play a role in the formation of ice accretions on swept wings. The results also pointed out the need to conduct flow field and heat transfer studies on swept wing models with roughness elements of the size observed in swept ice accretions to determine the effect on boundary layer transition flow field and heat transfer. Experimental, computational and analytical studies need to be conducted in this area.

\section{Effect of Large Roughness Elements on Boundary Layer Development, Flow Field and Heat Transfer}

The effect of large roughness elements on transition, flow field and heat transfer on a 3D boundary layer at the low Mach numbers encountered in icing is not known, but we will review the key icing related experimental studies of large roughness effects on transition, flow field and heat transfer that had been conducted for 2D boundary layers $^{39-43}$ because they provide some insights into what we may expect for the 3D boundary layer case, especially as it relates to the growth of feathers from roughness elements.

Henry, Hansman and Breuer ${ }^{43}$ investigated the local variation of heat transfer over roughness elements. A previous close-up video study ${ }^{14}$ had observed feather growth from roughness elements, with the feather growing on the upstream face of the element. This indicated that local enhancement in the heat transfer was the reason for the initiation of feather growth. An experimental setup, using Infrared (IR) measurement techniques, was designed to allow the measurement of the variation of heat transfer over individual roughness elements (Fig. 30a). The roughness elements (individual or multiple elements) were placed on a Plexiglass flat plate at a given distance from the leading edge of the plate. Under the assumption that conduction and radiation effects could be neglected, the 
heat enhancement (the ratio of the local heat transfer coefficient over a roughness element to the heat transfer coefficient at a location without roughness elements) could be obtained by measuring the surface temperatures at those locations and the temperature of the incoming air (Fig. 30b).

The IR camera allowed a noninvasive measurement of the heat enhancement. The heat transfer of individual elements was investigated with laminar and turbulent boundary layers. For a single element of a given height, at a given air velocity, the heat enhancement was found to start increasing at a distance of about 2-radii upstream from the center of the element, peak on the upstream surface of the element at a distance of one-half radius from the center of the element and decrease rapidly to about half the peak value at the wake (Fig. 31). The same pattern was followed for all the velocities but the larger elements had a higher peak and downstream enhancements. For the larger elements the maximum heat enhancement over a single element increased with Reynolds number and peaked at $\operatorname{Re}=3 \times 10^{5}$. They found that the maximum heat enhancement (peak heat enhancement on the upstream face of the element) increased as the ratio of the element height to the theoretical boundary layer thickness increased. When the height of the element was small compared to the boundary layer height the heat enhancement increased slowly. When the height of the element approaches the value of the boundary layer height the heat enhancement increased rapidly. As the roughness element protrudes from the boundary layer the heat enhancement increased roughly exponentially (Fig. 32).

The experiment was also conducted for turbulent boundary layers. The heat enhancement over a single element (of a given height and for a given air velocity) followed the same pattern as in the laminar boundary layer case but the heat enhancement curves did not change substantially from one velocity to another. The magnitude of the heat enhancement was lower because the heat transfer coefficient over an area without roughness elements is higher in the turbulent boundary layer case than in the laminar case. The maximum heat enhancement over a single element remained about constant with the Reynolds number but the magnitude was larger the taller roughness elements.

For the turbulent boundary layer, the heat transfer enhancement was measured for multiple roughness elements in four basic configurations. The height of all the elements in all the configurations was 1 millimeter. It was observed that if the elements were closely packed the heat enhancement was uniform. As the elements are separated from each other, the heat transfer enhancement over each element was similar to the one observed for single elements.

I cannot stress enough the importance of the Henry, Hansman and Breuer experiment as it relates to icing. Their experimental results tie the growth of feathers to local heat transfer effects over roughness elements. Work in this area is needed to determine if similar heat enhancement occurs for single and multiple roughness elements on a swept wing configuration. Heat transfer work needs to be complemented with measurements of boundary layer development and transition, and with flow visualization, all in the same swept wing configuration.

Winkler ${ }^{41}$ studied the local flow field about single and distributed roughness elements in a flat plate laminar boundary layer. He did flow visualization (smoke, oil) and LDV for a baseline isolated roughness element case and for distributed roughness. The ratio of the height of the element to the boundary layer, $k / \delta$, was 2.5 at a Reynolds number (based on the element height) of 3,700. The roughness Reynolds number and $k / \delta$ were scaled to match the typical values found for initial glaze ice accretions. For the distributed roughness pattern, the spacing was chosen to match the spacing observed on roughness characterization experiments. The flow structure around the isolated roughness element was extremely complex. An unsteady horse shoe vortex system was observed beginning upstream of the element and around it (Fig. 33). Downstream of the element he observed a recirculation region where peaks in the turbulent intensity contours were measured. This was the location of a hairpin-type of vortex. The flow field around the element is similar to the one observed by previous researchers during transition studies (Fig. 34). For the distributed roughness he observed in front of each element (in the first row) a horseshoe system with two primary vortices. Peaks in the turbulent intensity were detected at about each roughness element height and slightly downstream, stronger for elements in the front row and decreasing for elements downstream. In the wake, the vortical structures were weaker and less distinct than the hairpin-type vortex observed for isolated elements.

Correlation of the Winkler observations to Henry, Hansman and Breuer heat transfer results can only be speculative because the measurements were done without accompanying heat transfer measurements, but it is safe to say that the heat transfer in front of the element observed by Henry, Hansman and Breuer is located in the same area 
where a strong time-averaged vorticity in the horseshoe vortex system was found by Winkler. He also pointed out ${ }^{41}$ that: " it is therefore believed that the enhanced heat transfer previously measured over the distributed roughness is a result of the formation of vortical structures in the shear layers coming off the top of the elements, as well as the acceleration of the inviscid flow over the top of the elements". This observation is important because in some of the current computational efforts the first step has been to try to determine the heat enhancement by the acceleration of the flow before going into the complexity involved in simulating the more complex flow structures.

The Henry et al. and Winkler experiments were conducted for flow over flat plates with no pressure gradient. The next two experiments that I will discuss were conducted on an unswept NACA 0012. The boundary layer in this case is developing in a favorable pressure gradient.

Kerho ${ }^{39}$ conducted an experimental study to determine the effect of distributed roughness on the development of an airfoil boundary layer on an unswept NACA 0012, when the roughness elements are of a size comparable or larger than the boundary layer thickness. It is a very extensive and complete research work. I will only discuss one key result. He used hot-wire anemometry to conduct boundary layer measurements of mean and fluctuating velocity, turbulent intensity, flow field intermittency and frequency content and associated integral parameters. The Reynolds numbers (based on the height of the element) tested in the experiment ranged from 287 to 1182 (values at the leading edger of the roughness). The Reynolds numbers (based on the airfoil chord) tested were $0.75 \times 10^{6}$, $1.25 \times 10^{6}$ and $2.25 \times 10^{6}$. The extent of the distributed roughness was 0.125 ”, 0.250 ” and 0.5 ” at locations of $4,7,8$, 12,18 , and $24 \mathrm{~mm}$ from stagnation. His measurements showed that transition begins at, or very near the trailing edge of the roughness. Fully turbulent boundary layer was never observed to occur at the roughness location. The boundary layer covered a substantial chordwise extent before reaching fully developed turbulent state. The transition process observed was different from that observed for the clean model. Turbulent intensity levels in the transitional region were half the magnitude of those observed for the clean model in the transitional region. Intermittency values and turbulent intensity profiles developed from the wall up through the boundary layer.

Lee ${ }^{42}$ conducted heat transfer measurements by implementing Henry et al.'s setup on a NACA 0012 unswept airfoil with distributed roughness in a configuration similar to Kerho's. Because his setup was the same as Kerho's, he could relate the heat transfer results to the state of the boundary layer. Like Henry et al., he measured the heat transfer enhancement: the ratio of the heat transfer coefficient in the perturbed region to the heat transfer coefficient in a region of unperturbed laminar boundary layer at the same chordwise distance. He used distributed roughness of heights 0.35 and 0.75 millimeters, with the leading edge of the roughness located at 7 millimeters from the stagnation line. The Reynolds numbers (with respect to the chord of the airfoil) tested were $0.75 \times 10^{6}, 1.25 \times 10^{6}$ and $2.25 \times 10^{6}$. For the clean-model (no roughness) he observed that the IR lamps used to heat the airfoil did not alter the development of the boundary layer. Increasing the turbulence level in the tunnel to a level where the boundary layer is transitional from the leading edge did not significantly increase the heat transfer rate as long as the boundary layer near the wall remained laminar. For the leading edge roughness case he observed that the heat transfer rates over and immediately downstream of the roughness were higher than the turbulent smooth-wall values. Increasing the Reynolds number increased the heat transfer enhancement over and downstream of the roughness. Increasing free stream turbulence had no significant effect on heat transfer enhancement due to the leading edge roughness.

Since 1997, no additional icing related studies have been conducted on the effect of large roughness elements on transition, flow field and heat transfer on a 2D boundary layer. The work in this area is far from complete. The effect of pressure gradient has not been studied. The heat transfer and flow field studies were not conducted on the same configurations and a connection between the heat enhancement observed and the flow field was not established.

\section{Current Efforts Related to Modeling Scallop Formations}

Several research efforts are currently underway to understand the effects of large roughness elements on heat transfer and flow field. McClain et al. ${ }^{44}$ reviewed Henry et al.'s experiment and developed an Extended Surface, Discrete-Element (ES-DEM) analysis to examine their results. The analysis captured the trends of the heat enhancement versus Reynolds number reported by Henry et al., and the trends of the of the heat enhancement versus the ratio of the roughness element height to the boundary layer at the location. They examined the importance of 
thermal boundary layer thickness, the thermal conductivity of the roughness element and the radiation into the element.

Kreeger et al. ${ }^{45}$ conducted computational studies of the heat enhancement caused by the acceleration of the flow over an isolated 2D roughness elements in laminar flow when the element is located on a flat plate. The CFD analysis was conducted for $k / \delta$ values of 0.5 to 3.0 and Reynolds numbers (based on the element height) from 200 to 2000. The problem was extended to a 3D roughness element in turbulent flow. The work by Kreeger et al. and McClain et al. are computational and analytical initial steps towards the study of the flow field and heat transfer over distributed 3D large roughness elements.

Matheis and Rothmayer ${ }^{46}$ investigated the feasibility of using a Direct Numerical Simulation (DNS) approach to study the flow over roughness elements. They applied the DNS approach to the flow over a hemispherical roughness element on a flat plate, at a roughness Reynolds of 3700, and they compared to experimental data. They are extending the DNS approach to study the flow over roughness elements placed on an airfoil leading edge.

\section{Summary of Research Steps needed for Modeling Scallops}

The sketch below summarizes the research steps needed for modeling scallops.

Aerodynamic Testing

"What features need to be modeled"

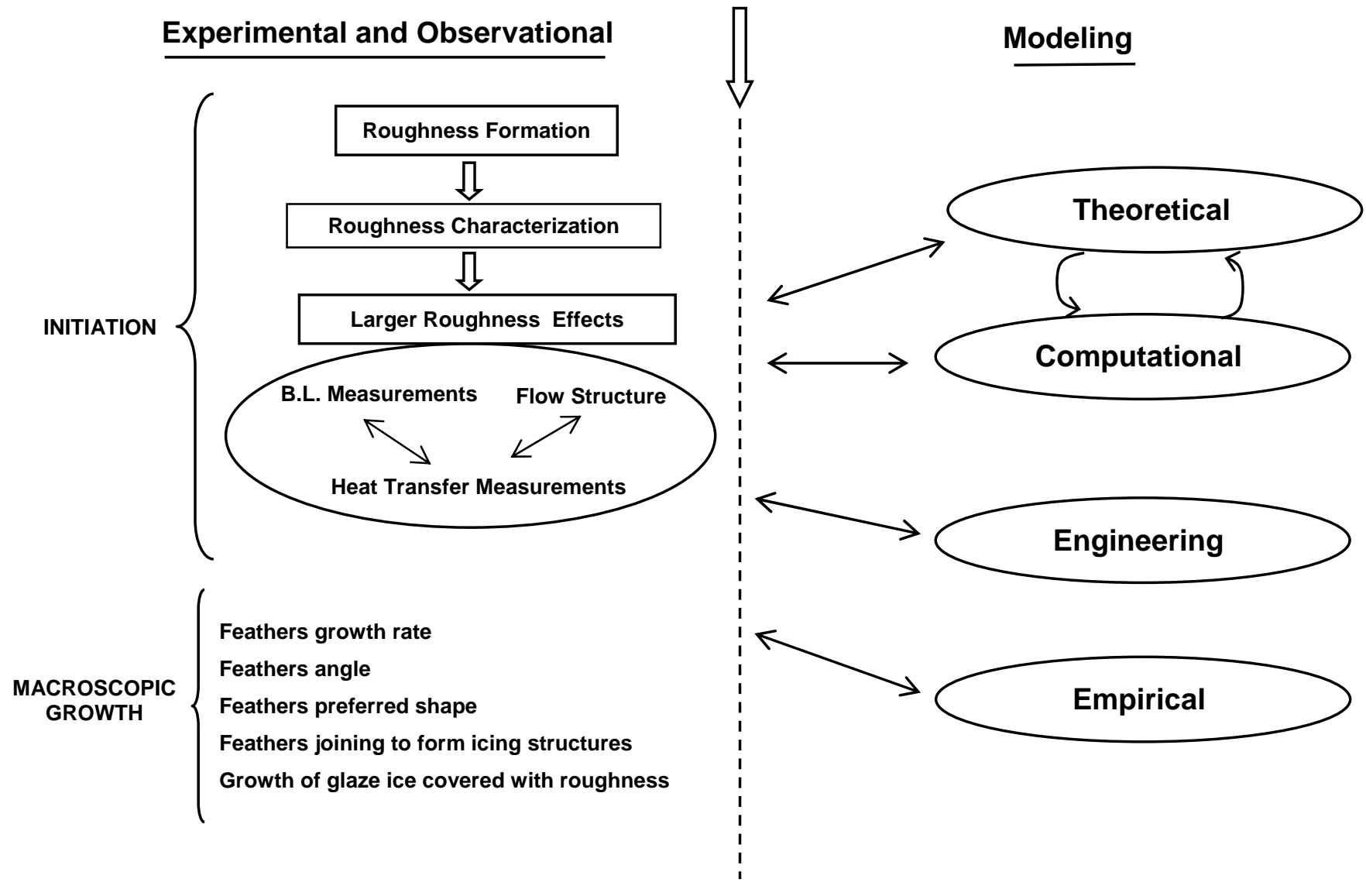

\section{Final Comments and Recommendations}

Through experiment and observation a great deal of understanding has been gained on how ice accretions form on swept wings and what are some of the important parameters. This has allowed us to define the conceptual steps needed for modeling and to identify the research work needed for its implementation. Additional research work is 
needed in areas such as roughness formation; roughness characterization; large roughness effects on boundary layer development, flow field and heat transfer; feather growth and feather interactions to form icing structures. This additional research effort should involve experimental, theoretical, computational, engineering and empirical approaches.

Recommendations:

- Experimental work should be conducted to validate current theoretical approaches on roughness formation.

- $\quad$ Experimental work should be initiated to obtain data on roughness size and distribution for given icing conditions on a swept wing configuration.

- The experimental work on large roughness effects on flow field and heat transfer should be completed for 2D configurations and extended to 3D. The experimental work should be conducted on the same configuration to allow establishing a connection between the flow field and the heat transfer. The effect of pressure gradient should be studied.

- Current computational and analytical work on the effects of single large roughness elements on heat transfer and flow field should be continued and extended to multiple roughness elements.

- Experimental data on feather growth should be obtained. It must include feather angle, feather growth rate, feather shape and feather alignment with respect to flow field.

- Analytical and computational modeling of feather initiation and growth must be supported.

- The database on aerodynamic effects of ice shapes formed on swept wings needs to be extended to a larger range of icing conditions that includes Supercooled Large Droplets (SLD).

- Studies should be conducted to determine the aerodynamic effect of scallop features. This will help to determine what features of scallop formation need to be modeled.

- $\quad$ Experimental and observational work done in the 90s showed the limitations involved when conducting icing physics experiments in a large engineering facility. To conduct the research needed for modeling ice accretions on swept wings a dedicated Icing Physics facility is needed to provide the experimental conditions and experimental control needed to validate theoretical and computational models, and to observe, study and measure new phenomena that the theoretical or computational models may have not considered. Current efforts in this direction should be fully supported.

\section{References}

${ }^{1}$ Von Glahn, U. H., and Gray, V. H., "Effect of Ice Formations on Section Drag of Swept NACA 63A-009 Airfoil with Partial-Span Leading-Edge Slat for Various Modes of Thermal Ice Protection”, NACA RM E53J30, March 15, 1954.

${ }^{2}$ Bowden, D. T., "Investigation of Porous Gas-Heated Leading-Edge Section for Icing Protection of a Delta Wing", NACA RM E54I03, January 19, 1955. Comment on scallops is on page 9. Photographic data is on pages 35 and 36.

${ }^{3}$ Rush, C. K., “The Icing of Delta Wings of Unity Aspect Ratio Having Leading Edge Separation”, National Research Laboratories, Ottawa, Canada, Report LR-268”, December 1959.

${ }^{4}$ Blair, S., "Ice Accretion Test for Two BAC Airfoils in the NASA Lewis Icing Research Tunnel”, Boeing Document T65049, August, 1967.

${ }^{5}$ Shah, A., "Statistical Experiment on Ice Accretion and Correlation of Ice Shapes for Swept Airfoils", Boeing Document D658363, May, 1969.

${ }^{6}$ Wilder, R. W., “A Theoretical and Experimental Means To Predict Ice Accretion Shapes for Evaluating Aircraft Handling and Performance Characteristics”, AGARD Advisory Report No. 127 Aircraft Icing, November 1978. 
${ }^{7}$ Laschka, B. and Jesse, R. E., "Ice Accretion and Its Effects on Aerodynamics of Unprotected Aircraft Components”, AGARD Advisory Report No. 127 Aircraft Icing, November 1978.

${ }^{8}$ Pierre, M. and Vaucheret, X., "Icing Test Facilities and Test Techniques in Europe”, AGARD Advisory Report No. 127 Aircraft Icing, November 1978.

${ }^{9}$ Armand, C., Charpin, F., Fasso, G. and Leclere, G., “Techniques and Facilities Used at the ONERA Mondane Center”, AGARD Advisory Report No. 127 Aircraft Icing, November 1978.

${ }^{10}$ Reehorst, A. L., "Prediction of Ice Accretion on a Swept NACA 0012 Airfoil and Comparisons to Flight Test Results", AIAA Paper 92-0043, Jan 1992.

${ }^{11}$ Hansman, R., Breuer, K., Hazan, D., Reehorst, A. L. and Vargas, M., “Close-up Analysis of Aircraft Ice Accretion”, AIAA Paper 93-0029, Jan 1993.

${ }^{12}$ Reehorst, A. L., Ratvasky, T. P. and Sims, J., “Close-up Analysis of Inflight Ice Accretion”, AIAA Paper 94-0804, Jan 1994.

${ }^{13}$ Hedde, T. and Guffond, D., "Improvement of the ONERA 3D Icing Code, Comparison with 3D Experimental Shapes", AIAA Paper 93-0169, Jan. 1993.

${ }^{14}$ Olsen, W. and Walker, E., "Experimental Evidence for Modifying the Current Physical Model for Ice Accretion on Aircraft Surfaces”, NASA TM-87184, 1986.

${ }^{15}$ Vargas, M., "Ice Accretion on Swept Wings at Glaze Ice Conditions”, Ph.D. Thesis, Case Western Reserve University, Cleveland, Ohio, May1998.

${ }^{16}$ Vargas, M. and Reshotko, E., "Physical Mechanisms of Glaze Ice Scallop Formations on Swept Wings”, AIAA Paper 980491and NASA TM-1998-206616, Jan. 1998.

${ }^{17}$ Vargas, M. and Reshotko, E., "Parametric Experimental Study of the Formation of Glaze Ice Shapes on Swept Wings", AIAA Paper 99-0094, Jan. 1999.

${ }^{18}$ Vargas, M. and Reshotko, E., "LWC and Temperature Effects on Ice Accretion Formation on Swept Wings at Glaze Ice Conditions”, AIAA Paper 2000-00483, Jan. 2000.

${ }^{19}$ Vargas, M., Giriunas, J. and Ratvasky, T., "Ice Accretion Formations on a NACA 0012 Swept Wing Tip in Natural Icing Conditions”, AIAA Paper 2002-0244, Jan. 2002.

${ }^{20}$ The research program was lead by Dr. James Riley and Mr. Eugene Hill from the FAA. The NASA team members were: Dr. Mario Vargas, Dr. Mark Potapczuk, Mr. Harold Addy, Mr. David Sheldon, Mr. Julius Giriunas and Mr. David Brinker. The Wichita State University team members were: Dr. Michael Papadakis, Dr. Hsiung-Wei Yeong and Dr. See-Cheuk Won.

${ }^{21}$ Vargas, M., Papadakis, M., Potapczuk, M., Addy, H., Sheldon, D. and Giriunas, J., "Ice Accretions on a Swept GLC-305 Airfoil”, SAE Paper 02GAA-43 and NASA TM-2002-211557, April 2002.

${ }^{22}$ Potapczuk, M., Papadakis, M. and Vargas, M., “LEWICE Modeling of Swept Wing Ice Accretions”, AIAA Paper 20036565, Jan. 2003.

${ }^{23}$ Papadakis, M., Yeong, H. W., Won, S. C., Vargas, M. and Potapczuk, M., “Aerodynamic Performance of a Swept Wing with Ice Accretions”, AIAA Paper 2003-0731, Jan. 2003.

${ }^{24}$ Papadakis, M., Yeong, H. W., Won, S. C., Vargas, M. and Potapczuk, M., "Experimental Investigation of Ice Accretion Effects on a Swept Wing”, FAA Contractor Report, 2003.

${ }^{25}$ Shin, J., "Characterization of Surface Roughness Associated with Leading Edge Ice Accretion” NASA TM 106459 and AIAA 94-0799, Jan. 1994.

${ }^{26}$ Anderson, D. N. and Shin J., “Characterization of Ice Roughness from Simulated Icing Encounters” NASA TM 107400 and AIAA 97-0052, Jan. 1997.

${ }^{27}$ Anderson, D. N., Hentschel, D. and Ruff G., "Measurement and Correlation of Ice Accretion Roughness" AIAA 98-00486 and NASA/CR 2003-211823, June 2003.

${ }^{28}$ Tsao, J. C., “Cross Flow Effects on Glaze Ice Roughness Formation”, AIAA Paper 2003-1219, Jan. 2003.

${ }^{29}$ Tsao, J. C., Rothmayer, A. P., “Application of Triple-Deck Theory to the Prediction of Glaze Ice Roughness Formation on an Airfoil Leading Edge”, Computers \& Fluids, Vol. 31, pp. 977-1014, 2002.

${ }^{30}$ Tsao, J. C., Rothmayer, A. P. and Ruban, A. I., "Stability of Air Flow Past Thin Liquid Films on Airfoils", Computers \& Fluids, Vol 26, No.5, pp 427-452, 1997.

${ }^{31}$ Tsao, J. C. and Rothmayer, A. P., “A Mechanism for Ice Roughness Formation on an Airfoil Leading Edge, Contributing to Glaze Ice Accretion”, AIAA-98-0485, Jan. 1998.

${ }^{32}$ Saric, W. S., "Laminar-Turbulent Transition: Fundamentals", AGARD Report No. 786 (Special Course on Skin Friction Drag Reduction), Rhode-St.Genese, Belgium, 1992.

${ }^{33}$ Reed, H. L. and Saric, W. S., "Stability of Three-Dimensional Boundary Layers”, Ann. Rev. Fluid Mechanics, Volume 21, Pages 235-284, 1989.

${ }^{34}$ Arnal, D., “Three-Dimensional Boundary Layers: Laminar-Turbulent Transition”, AGARD Report No. 741 (Computation of Three-Dimensional Boundary Layers Including Separation), Rhode-St.Genese, Belgium, 1986.

${ }^{35}$ Dagenhart, J. R., Saric, W. S., Mousseux, M. and Stack, J. P., “Crossflow-Vortex Instability and Transition on a 45-Degree Swept Wing”, AIAA Paper No. 89-1892, June 1989.

${ }^{36}$ Poll, D. I. A., “Transition Description and Prediction in Three-Dimensional Flows”, AGARD Report No. 709 (Special Course on Stability and Transition of Laminar Flows), VKI, Brussels, 1984.

${ }^{37}$ Reshotko, E., Vargas, M. and Reed, H., "Relation of Glaze Ice Formations on Swept Wings to Crossflow Instability", $5^{\text {th }}$ IUTAM Symposium on Laminar-Turbulent Transition, Sedona, AZ, U.S.A., Sep. 1999. 
${ }^{38}$ Reshotko, E., Vargas, M. and Reed, H., "Ice Formation on Swept Wings-Relation to Crossflow Instability”, Bulletin of the American Physical Society, Vol 43, No. 9, page 1993, Nov. 1998.

${ }^{39}$ Kerho, M. F., "Effect of Large Distributed Roughness Near an Airfoil Leading Edge on Boundary-Layer Development and Transition,” Ph.D. Dissertation, University of Illinois at Urbana-Champaign, 1995.

${ }^{40}$ Cummings, M. J., "Airfoil Boundary-Layer Transition Due to Large Isolated 3-D Roughness Elements in a Favorable Pressure Gradient”, Master Thesis, University of Illinois at Urbana-Champaign, 1995.

${ }^{41}$ Winkler, J. F., “Local Flowfield About Large Distributed Roughness Elements in a Laminar Boundary Layer,” Ph.D. Dissertation, University of Illinois at Urbana-Champaign, 1996.

${ }^{42}$ Lee, S., "Heat Transfer on an Airfoil with Large Distributed Leading-Edge Roughness" Master Thesis, University of Illinois at Urbana-Champaign, 1997.

${ }^{43}$ Henry, R. C., Hansman, R. J., Breuer, K. S., “Heat Transfer Variation on Protuberances and Surface Roughness Elements”, Journal of Thermophysics and Heat Transfer, vol 9, No. 1, March 1995.

${ }^{44}$ McClain, S. T., Vargas, M., Kreeger, R. E., Tsao, J. C., "Heat Transfer from Protuberances and Roughness Elements in Laminar and Turbulent Flow: A Reexamination of Henry, et al." to be published 2006.

${ }^{45}$ Kreeger, R. E., Vargas, M., McClain, S. T., "Heat Transfer Over Roughness Elements Larger than the Boundary Layer” to be published 2005.

${ }^{46}$ Matheis, B.D.., Rothmayer, A. P., "Impact of Surface Roughness on Local Aerodynamics Using a Three-Dimensional Navier-Stokes Solver”, AIAA Paper 2004-0058, January 2004.

Table 1. Summary of IRT Ice Shape Castings and Corresponding Icing Conditions. From Papadakis et al. ${ }^{23,24}$

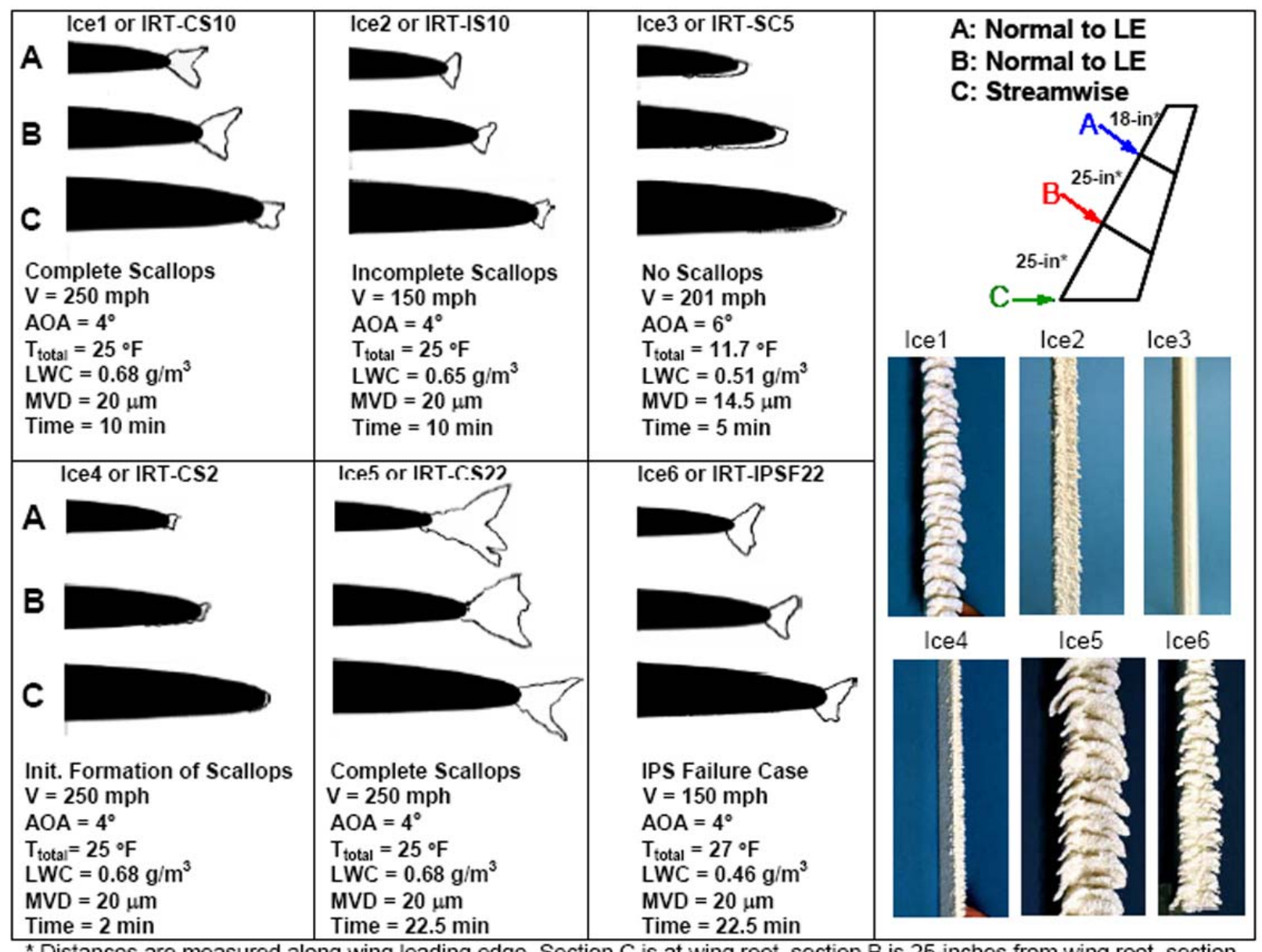

* Distances are measured along wing leading edge. Section C is at wing root, section B is 25-inches from wing root, section $A$ is 50 inches from wing root or 18 inches from wing tip. 


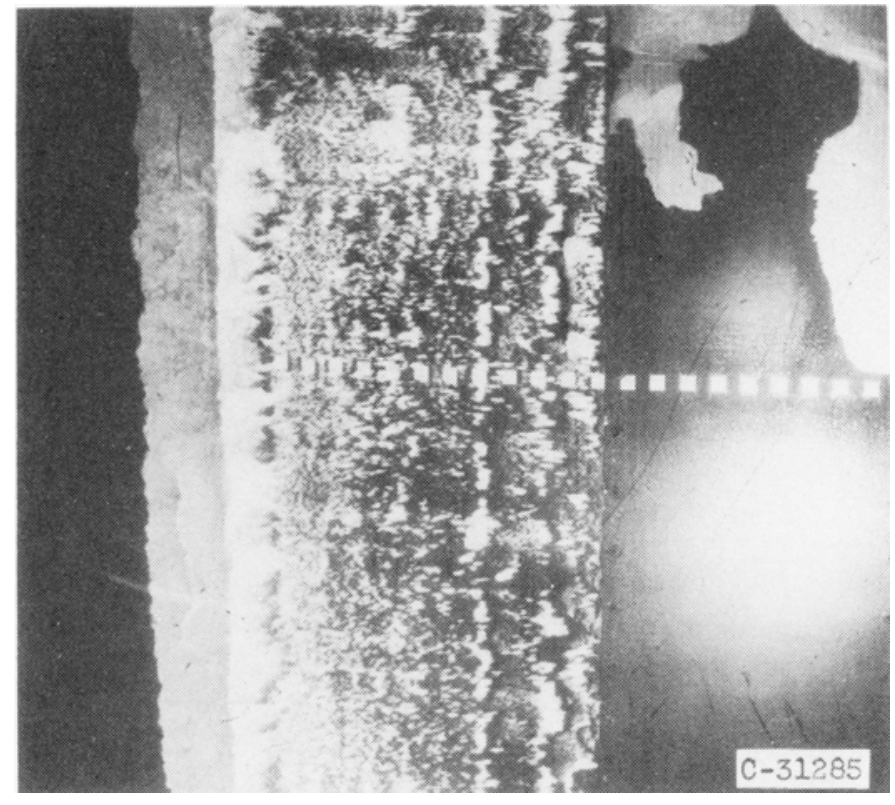

Figure 1. Ice accretion on NACA 63A-009 airfoil at $0^{\circ}$ sweep angle. From Von Glahn et al. ${ }^{1}(1954)$

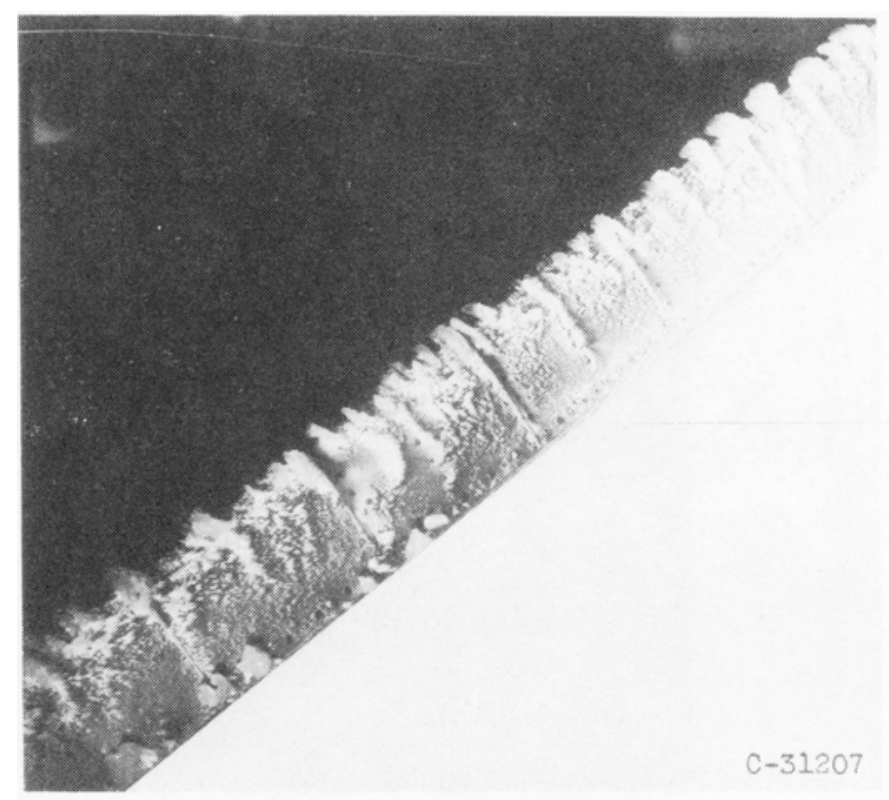

Figure 3. Scallop formations on NACA 63A-009 airfoil at $60^{\circ}$ sweep angle. From Von Glahn et al. ${ }^{1}(1954)$

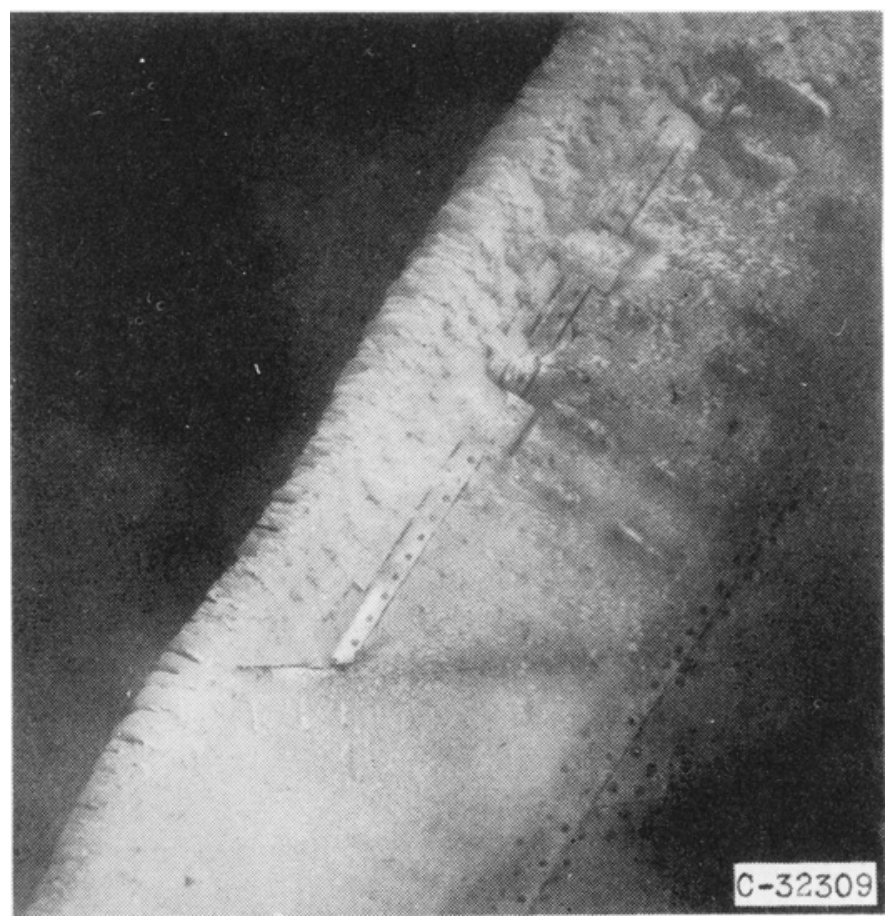

Figure 2. Ice accretion on NACA 63A-009 airfoil at $36^{\circ}$ sweep angle. From Von Glahn et al. ${ }^{1}(1954)$

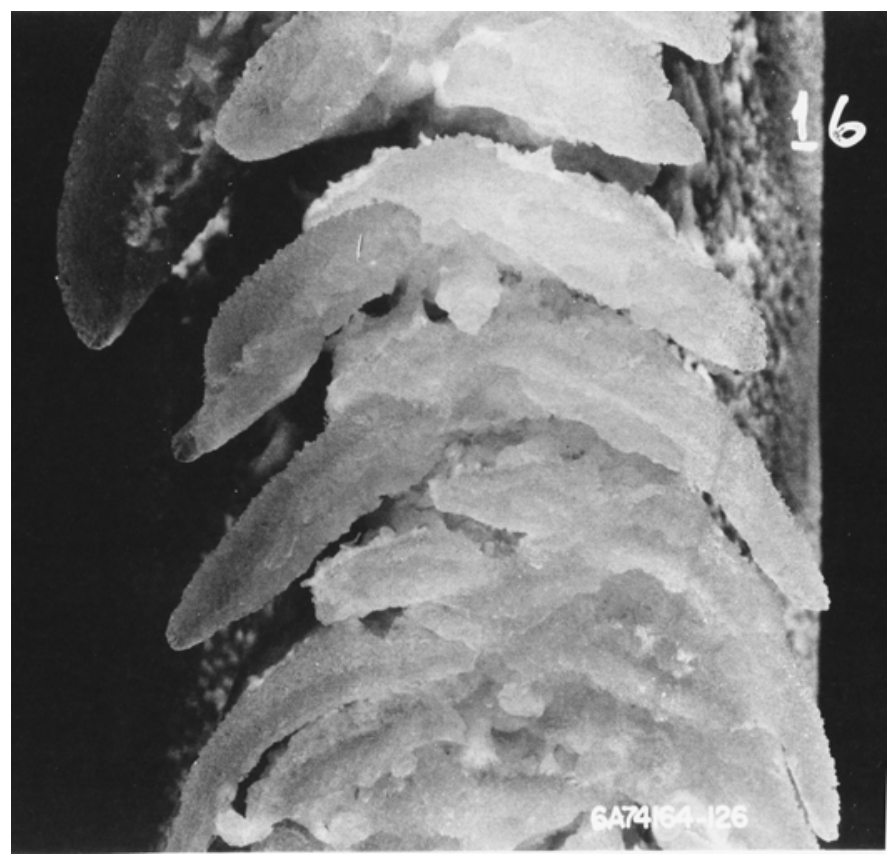

Figure 4. Frontal view of scallop formation on BAC 470. From Shah ${ }^{5}$ (1969) 

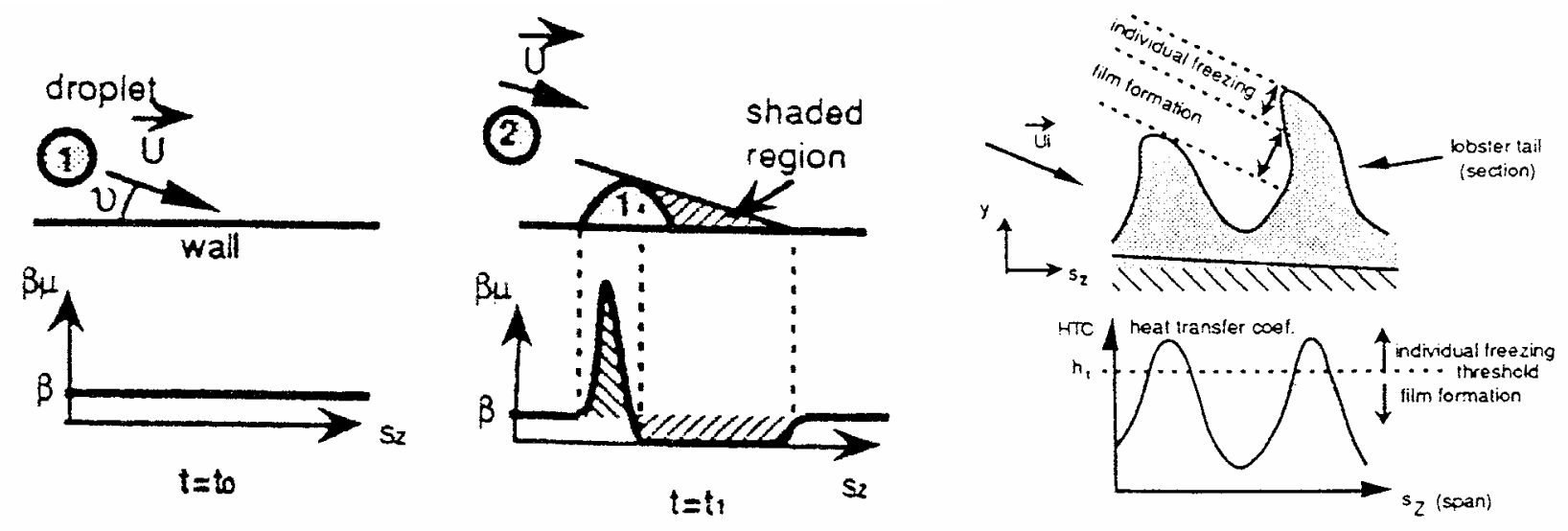

Figure 5. Hedde-Guffond two-step model of scallop formation. From Hedde and Guffond ${ }^{13}$ (1993)

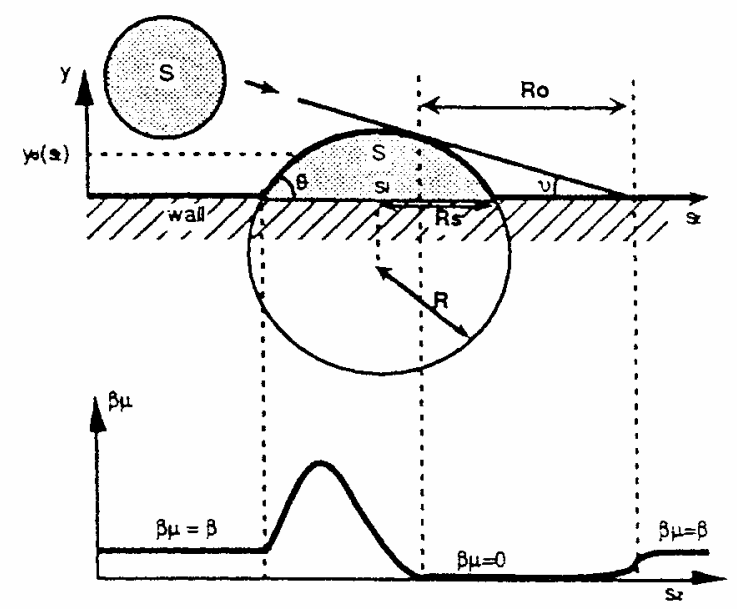

$$
R=\sqrt{\frac{S}{\theta \cdot 0.5 \sin (2 \theta)}}
$$

Then we find the shape $y_{d}$ on the wall is (when $y_{d}>0$ ):

$$
\begin{aligned}
y_{d}\left(s_{z}\right)= & \sqrt{R^{2}-\left(s_{z}-s_{j}\right)^{2}} \cdot R \cos \theta \\
\text { where } & y_{d} \text { is the squashed droplet height, } \\
& s_{i} \text { is the span impingement point. } \\
& s_{z} \text { is the span coordinate. }
\end{aligned}
$$

We may calculate the droplei spreading radius Rs:

$$
R s=R \sin \theta
$$

Thus the MACKLIN spreading factor $S_{M}$ is :

$$
s_{M}=\frac{r}{R S}
$$

Figure 6. Application of Hedde-Guffond scallop model to a 2D Ballistic Model of scallop formation. From Hedde and Guffond ${ }^{13}$ (1993)

Figure 7. Parameters calculated in the 2D Ballistic Model of scallop formation. From Hedde and Guffond ${ }^{13}$ (1993) 


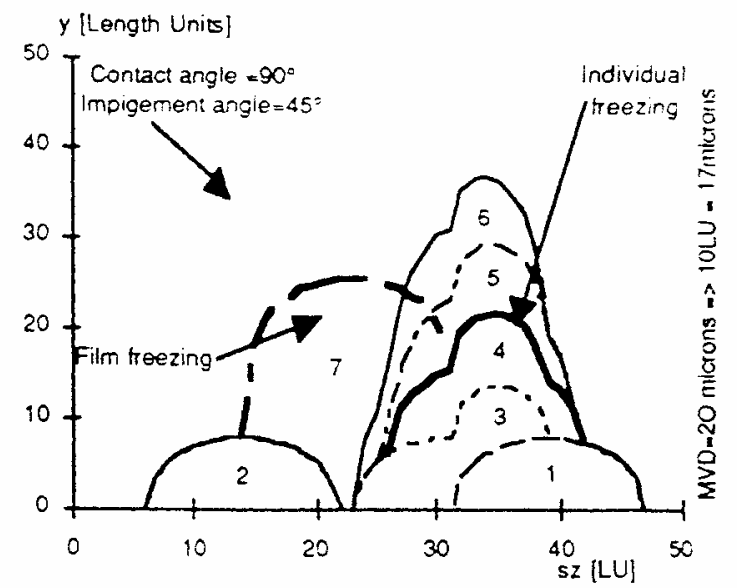

Figure 8. Scallop spacing calculated with the 2D Ballistic Model. From Hedde and Guffond ${ }^{13}$ (1993)

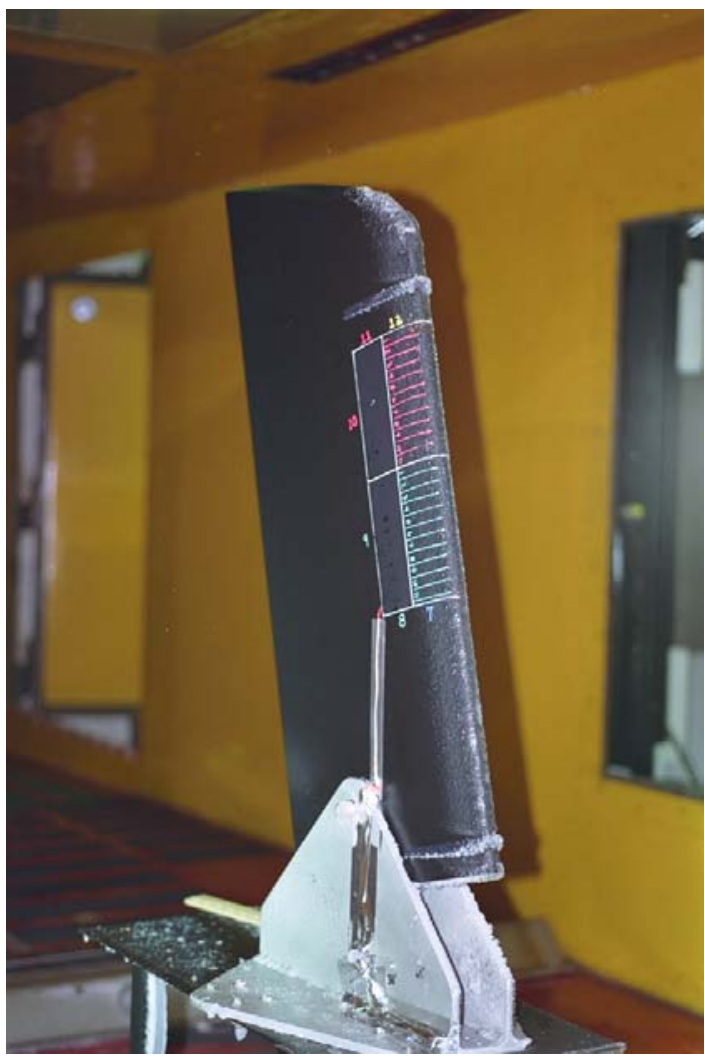

Figure 10. NACA 0012 swept wing tip in the IRT Test Section. From Vargas and Reshotko $^{16}$ (1998).

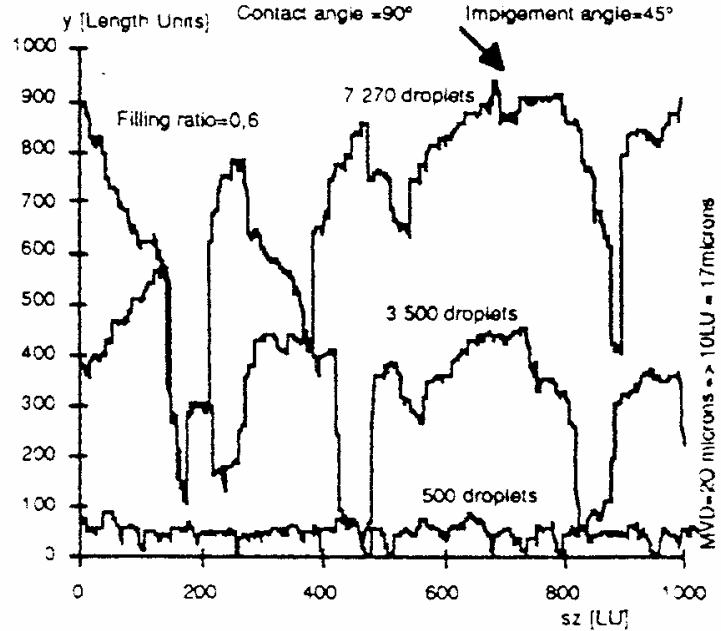

Figure 9. Scallop growth in the 2D Ballistic Model. From Hedde and Guffond ${ }^{13}$ (1993)

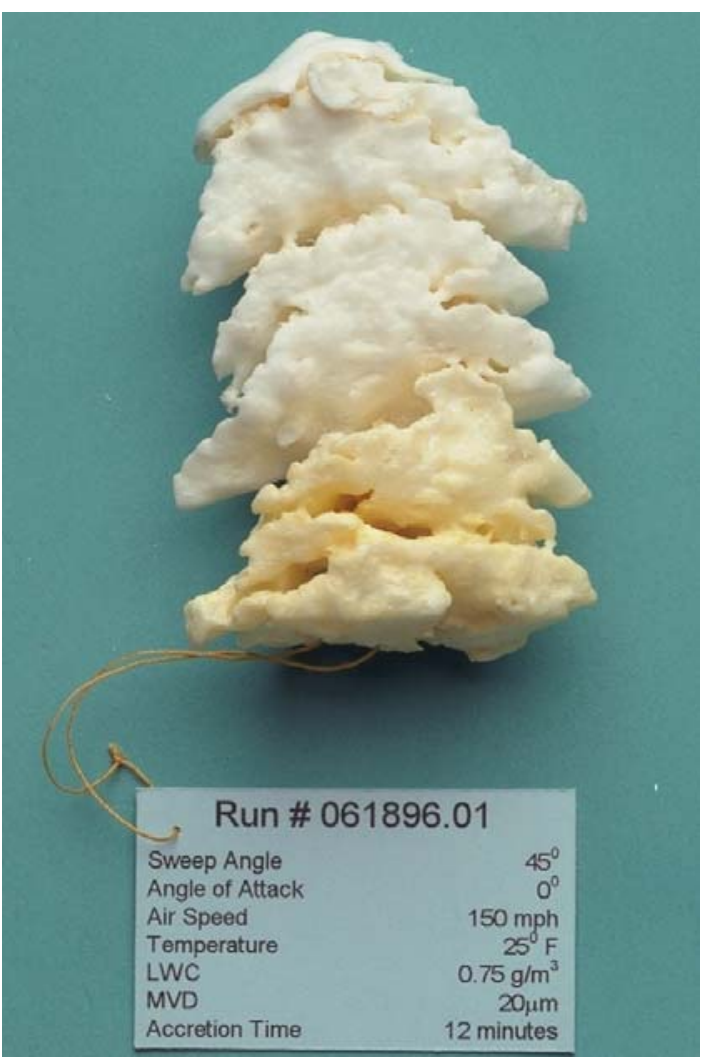

Figure 11. Urethane casting of an ice accretion. From Vargas and Reshotko ${ }^{16}(1998)$. 


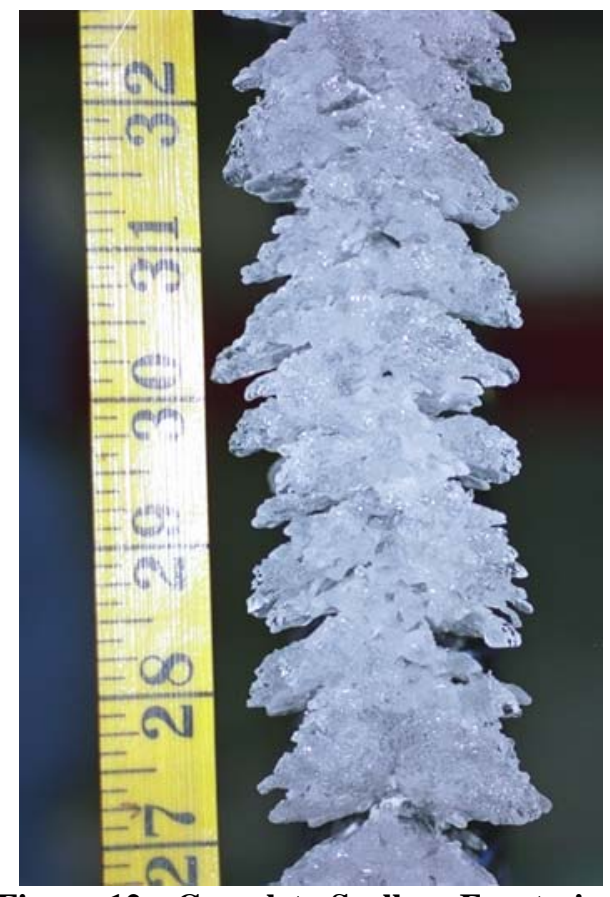

Figure 12. Complete Scallop. Front view of ice accretion for base case, showing large pointed ice structures called scallops. $\Lambda=45^{\circ}, V=150 \mathrm{mph}, \mathrm{T}_{\text {total }}=25^{\circ} \mathrm{F}$, $\mathrm{LWC}=0.75 \mathrm{~g} / \mathrm{m}^{3}, \quad \mathrm{MVD}=20 \mu \mathrm{m}, \tau=12 \mathrm{~min}$. Direction of flow is from bottom to top, scale of ruler is in inches. From Vargas and Reshotko ${ }^{16}$ (1998).

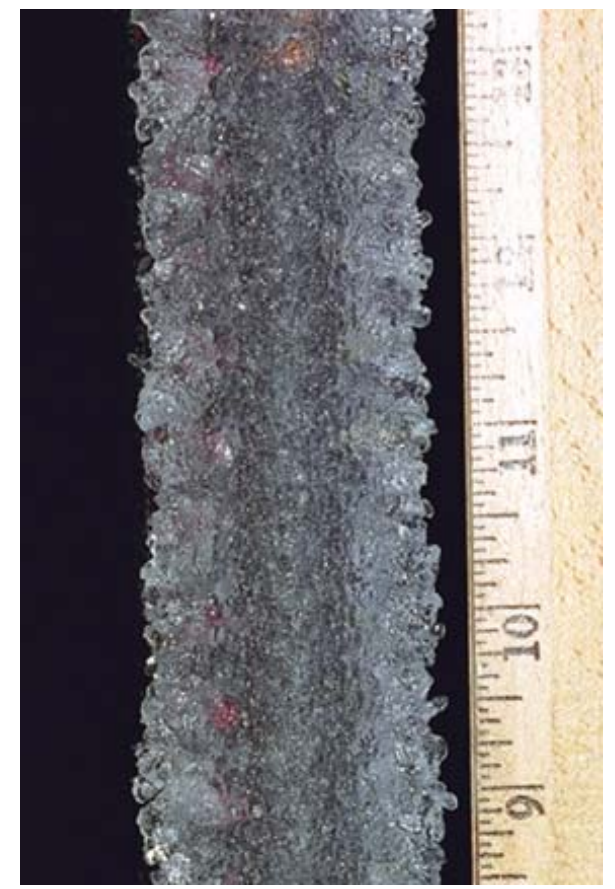

Figure 14. No-Scallop. Front view of ice accretion for base case, showing large pointed ice structures called scallops. $\Lambda=15^{\circ}, \quad \mathrm{V}=150 \quad \mathrm{mph}, \quad \mathrm{T}_{\text {total }}=25^{\circ} \mathrm{F}$, $\mathrm{LWC}=0.75 \mathrm{~g} / \mathrm{m}^{3}, \quad \mathrm{MVD}=20 \mu \mathrm{m}, \tau=8 \mathrm{~min}$. Direction of flow is from bottom to top, scale of ruler is in inches. From Vargas ${ }^{15}$ (1998).

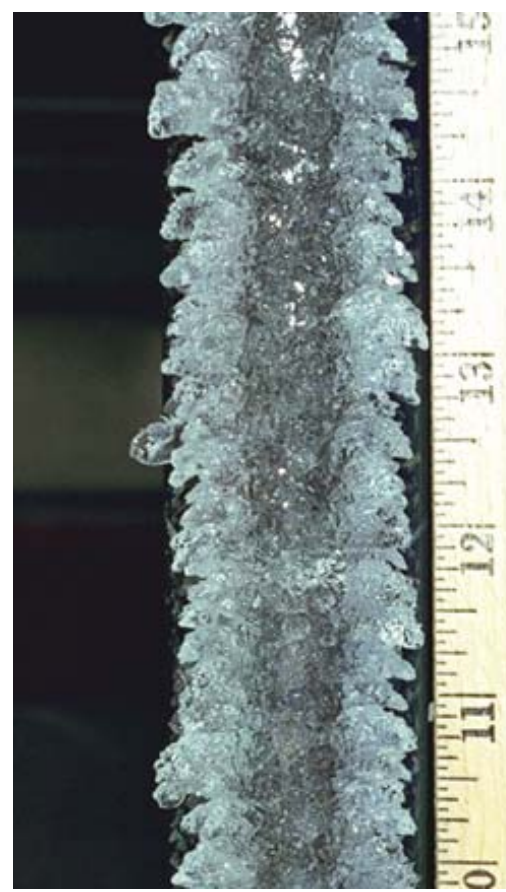

Figure 13. Incomplete Scallop. Front view of ice accretion for base case, showing large pointed ice structures called scallops. $\Lambda=30^{\circ}, \quad \mathrm{V}=150 \mathrm{mph}$, $\mathrm{T}_{\text {total }}=25^{\circ} \mathrm{F}, \mathrm{LWC}=0.75 \mathrm{~g} / \mathrm{m}^{3}, \mathrm{MVD}=20 \mu \mathrm{m}$, $\tau=8 \mathrm{~min}$. Direction of flow is from bottom to top, scale of ruler is in inches. From Vargas $^{15}$ (1998).

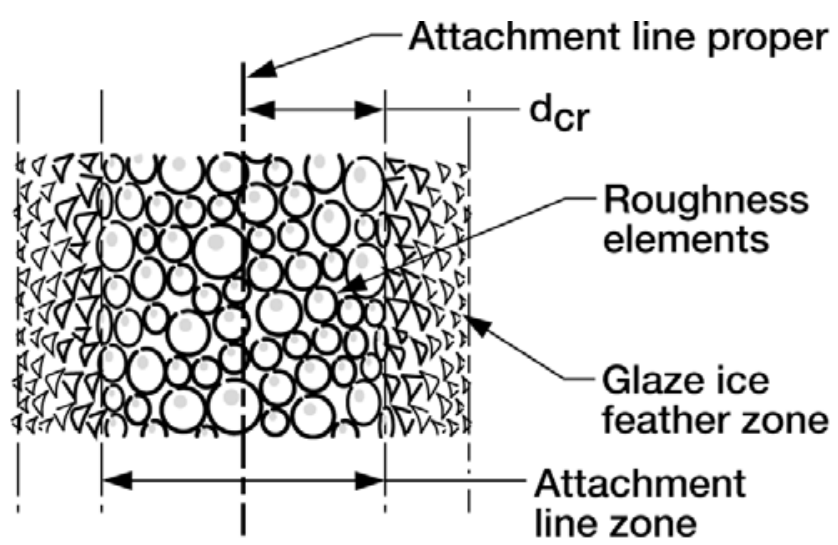

Figure 15. Drawing showing the definition of the critical distance: the distance from the attachment line zone to the location where the roughness elements become feathers. The drawing also includes the attachment line zone and the glaze ice feather zone. From Vargas and Reshotko ${ }^{18}$ (2000). 


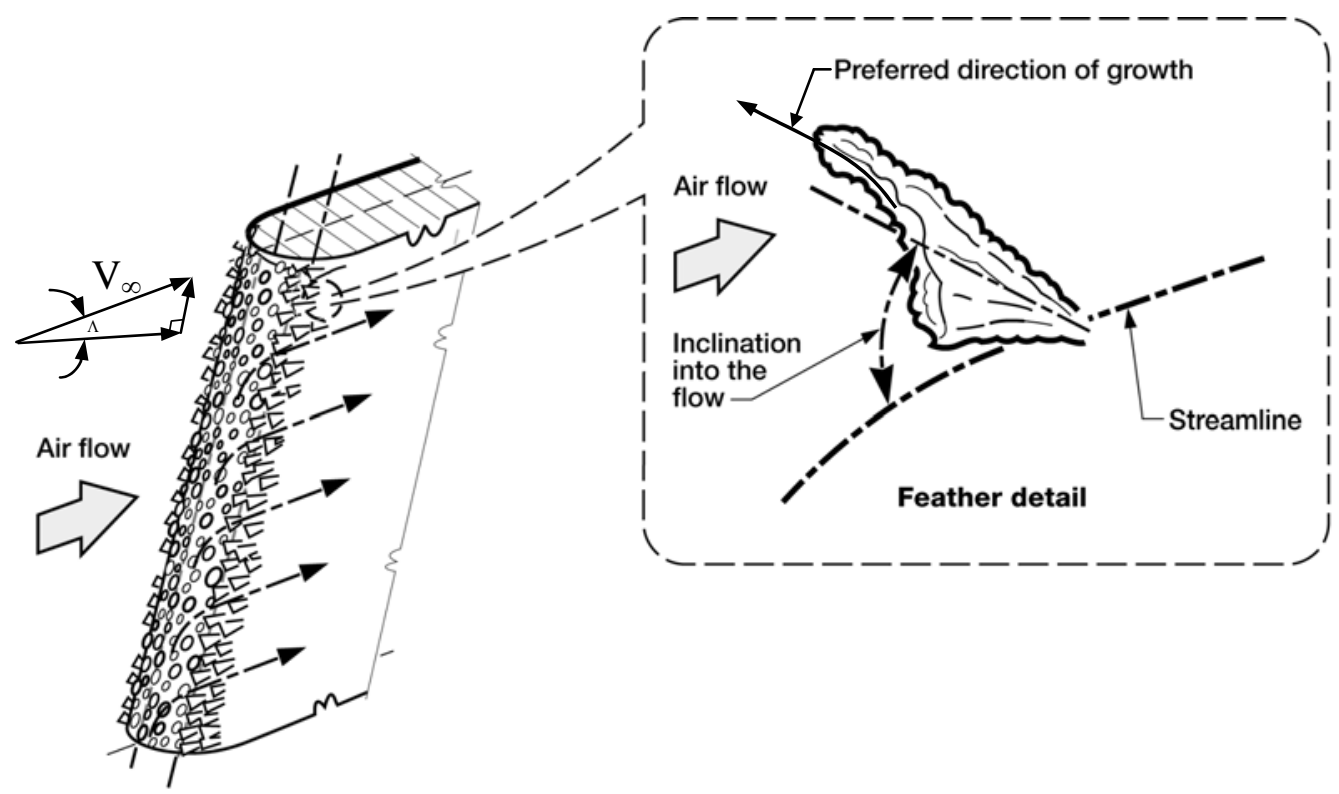

Figure 16. Glaze ice feathers with preferred direction of growth perpendicular to external streamline. Note that feathers have a tooth shape and are inclined into the flow. From Vargas and Reshotko $^{18}$ (2000).

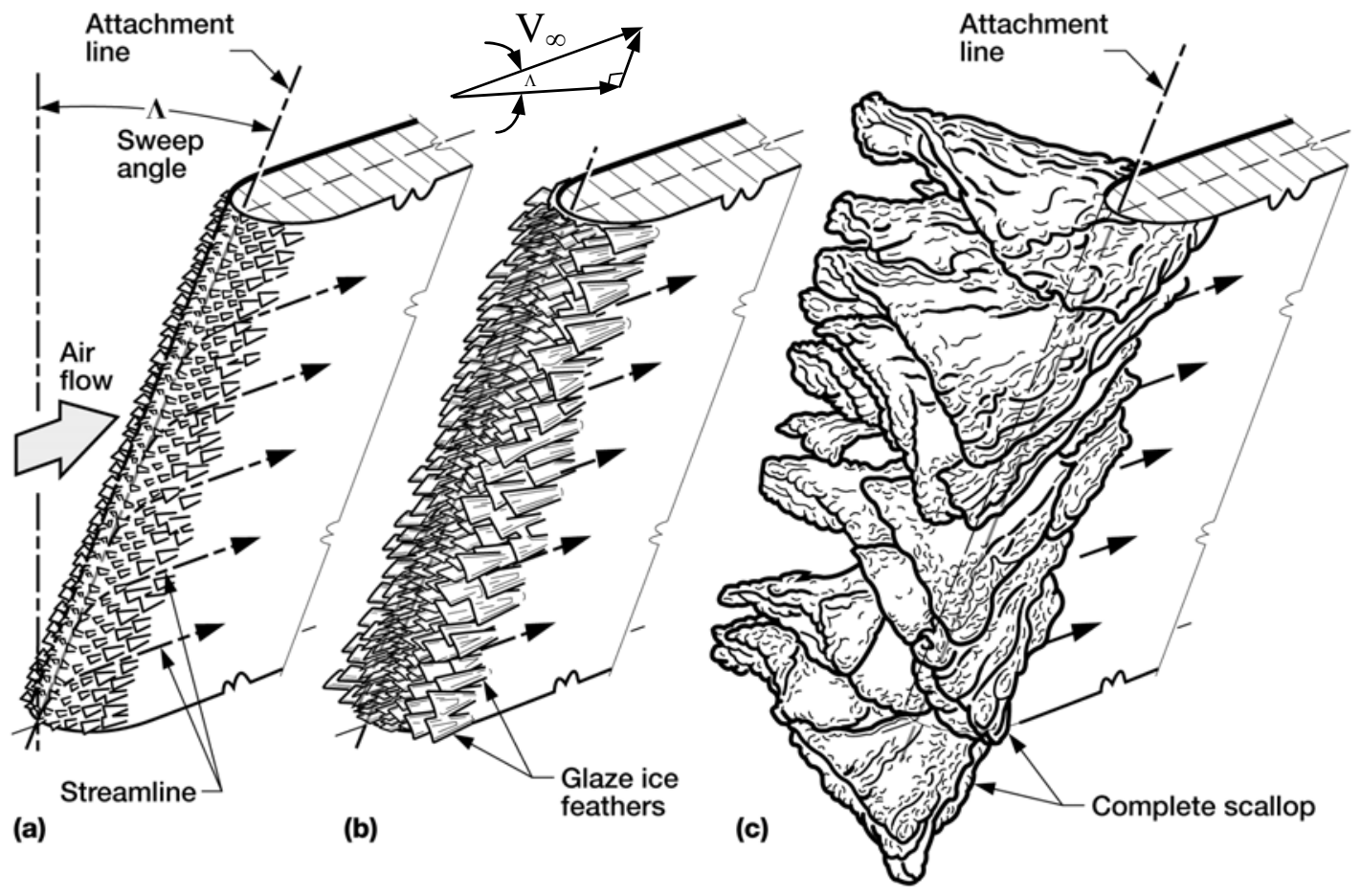

Figure 17. Ice accretion on a swept wing at glaze ice conditions, complete scallop case, critical distance $=\mathbf{0}$. (a) Roughness elements (all over the ice accretion) develop into glaze ice feathers with a preferred direction of growth perpendicular to the external streamlines. (b) The feathers join along the preferred direction of growth to form ridges that will develop into incipient scallop tips. (c) Incipient scallop tips join at their tops to form complete scallops. From Vargas and Reshotko ${ }^{18}$ (2000). 

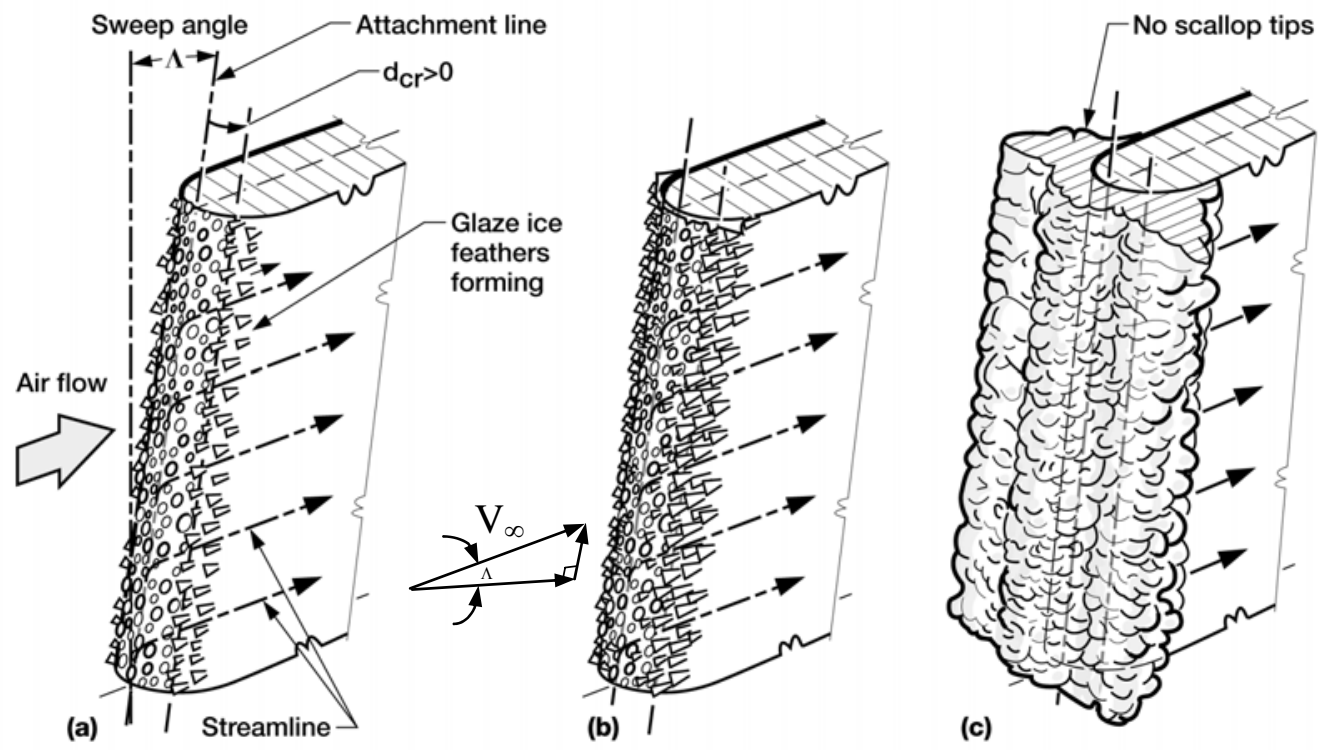

Figure 18. Ice accretion on a swept wing at glaze ice conditions, no-scallop case, critical distance $>0$. (a) Well defined attachment line zone and glaze ice feathers zone. (b) The feathers' preferred direction of growth is nearly parallel to the attachment line direction. This does not allow the mechanisms of scallop tip formation to operate. (c) Scallop tips are not formed. Attachment line ice eventually covers the feathers and spills on the side. From Vargas and Reshotko ${ }^{18}(2000)$.

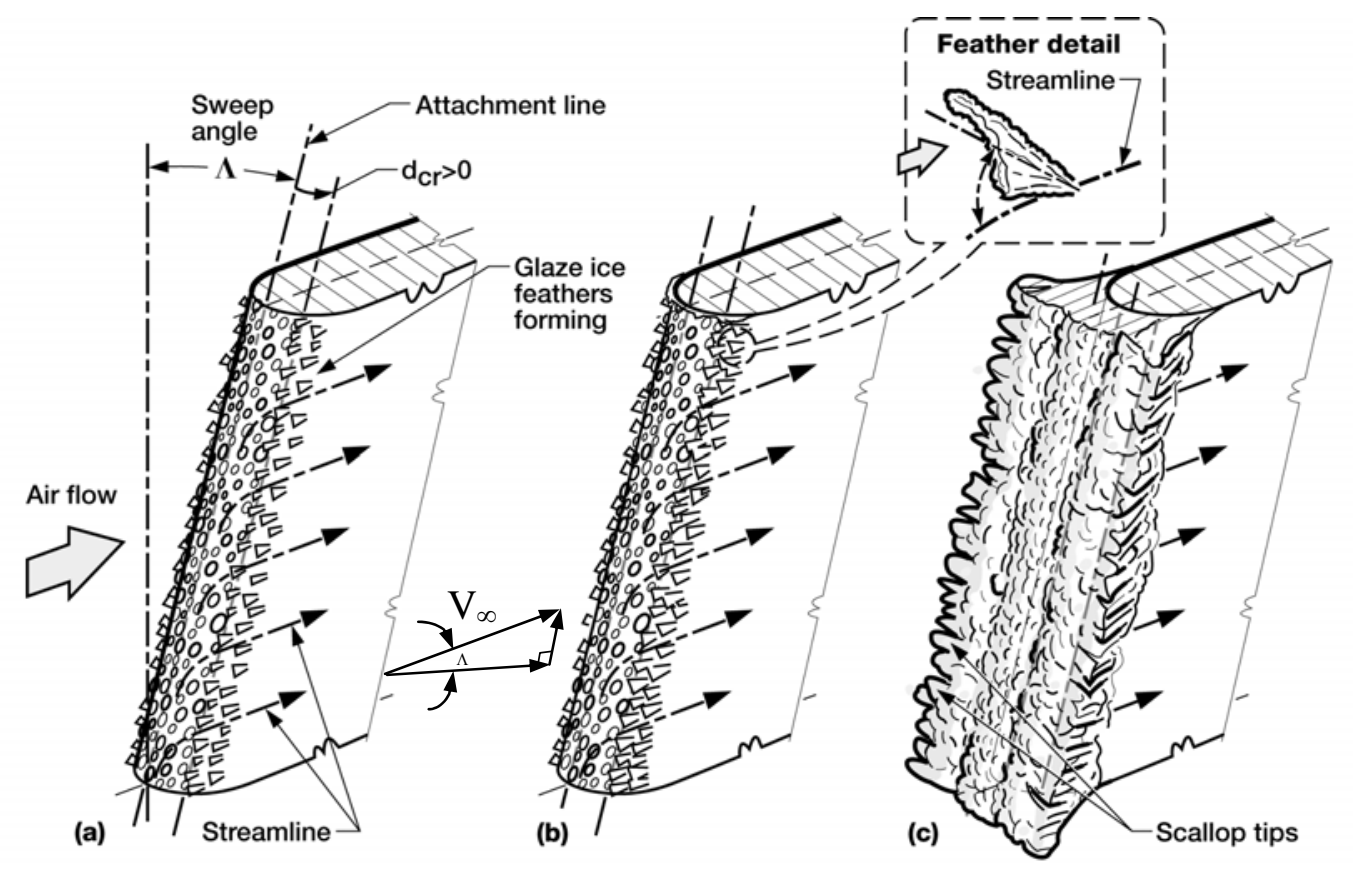

Figure 19. Ice accretion on a swept wing at glaze ice conditions, incomplete scallop case, critical distance $>0$. (a) Well defined attachment line zone and glaze ice feathers zone. (b) The feathers' preferred direction of growth is aligned at a large enough angle with respect to the attachment line direction. The mechanisms of scallop tip formation can operate. (c) Scallop tips are formed starting at a given distance (the critical distance) from the attachment line proper. From Vargas and Reshotko ${ }^{18}(2000)$. 


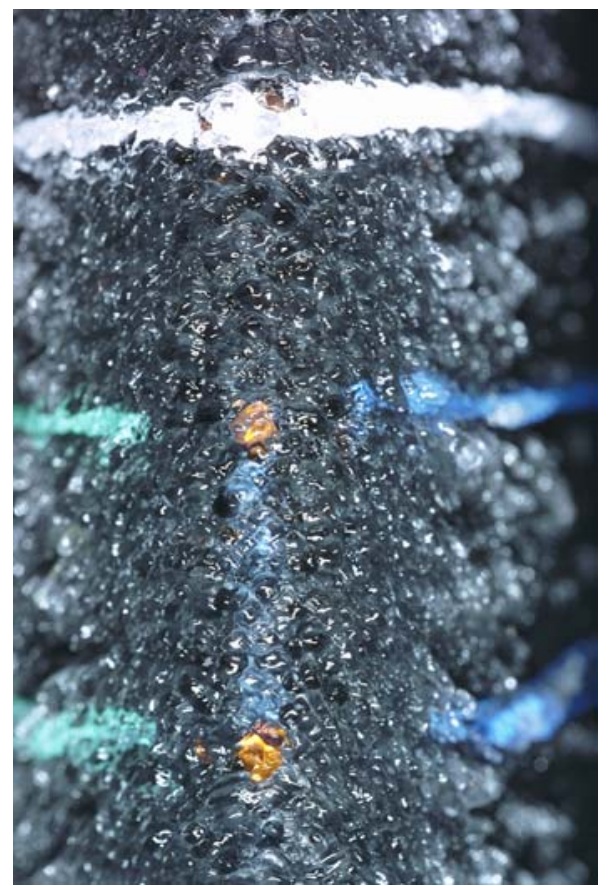

Figure 20. Close-up view of ice accretion at 1 minute, showing roughness elements. $\Lambda=45^{\circ}, \quad V=150$ $\mathrm{mph}, \quad \mathrm{T}_{\text {total }}=25^{\circ} \mathrm{F}, \quad \mathrm{LWC}=0.75 \mathrm{~g} / \mathrm{m}^{3}$, MVD $=20 \mu \mathrm{m}, \tau=1 \mathrm{~min}$. Direction of flow is from bottom to top, separation between stripes is approximately 13 mm. From Vargas and Reshotko ${ }^{15,16}$ (1998).

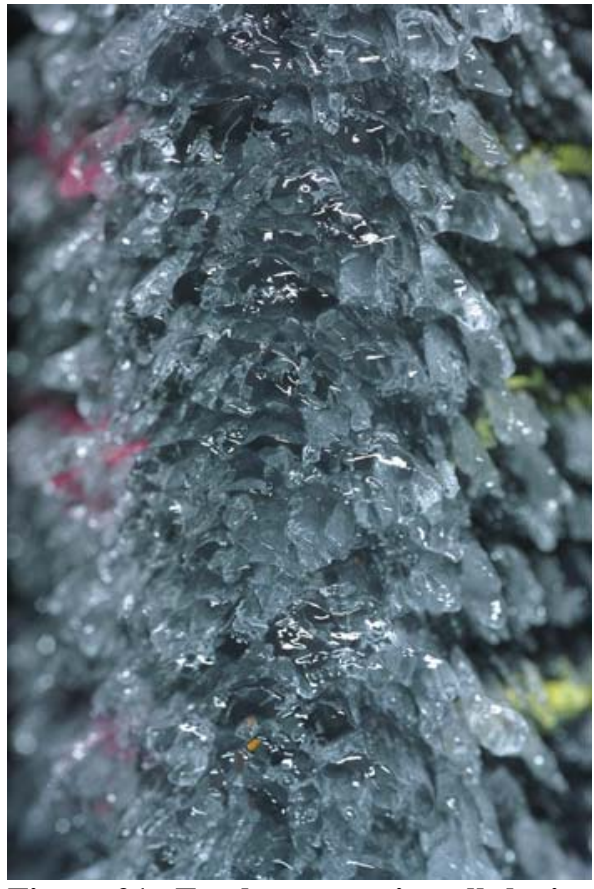

Figure 21. Feathers covering all the ice accretion at 2 minutes. $\Lambda=45^{\circ}, V=150$ $\mathrm{mph}, \quad \mathrm{T}_{\text {total }}=25^{\circ} \mathrm{F}, \quad \mathrm{LWC}=0.75 \mathrm{~g} / \mathrm{m}^{3}$, MVD $=20 \mu \mathrm{m}, \tau=2 \mathrm{~min}$. Direction of flow is from bottom to top, separation between stripes is approximately 13 mm. From Vargas and Reshotko ${ }^{15,16}$ (1998).

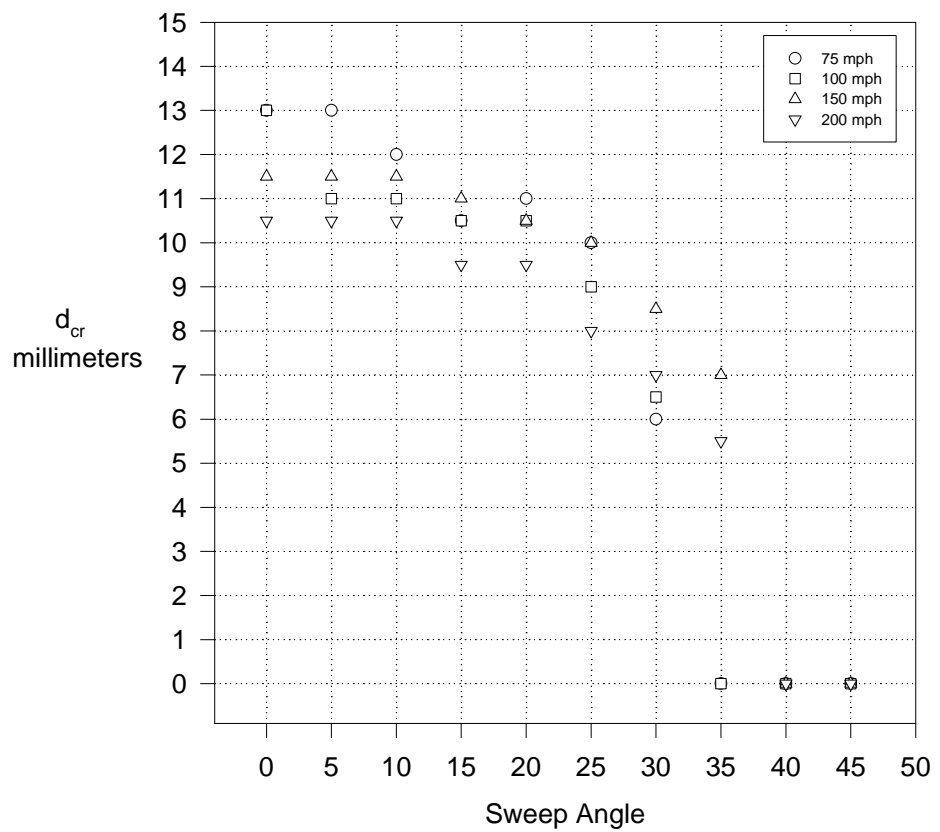

Figure 22. Change in critical distance with sweep angles for velocities of $75,100,150$ and $200 \mathrm{mph} . \Lambda=0^{\circ}$ to $45^{\circ}$ at $5^{\circ}$ increments, $T_{\text {total }}=25^{\circ} \mathrm{F}, L W C=0.8 \mathrm{~g} / \mathrm{m}^{3}, M V D=20 \mu \mathrm{m}, \tau=5 \mathrm{~min}$. From Vargas and Reshotko ${ }^{17}$ (1999). 


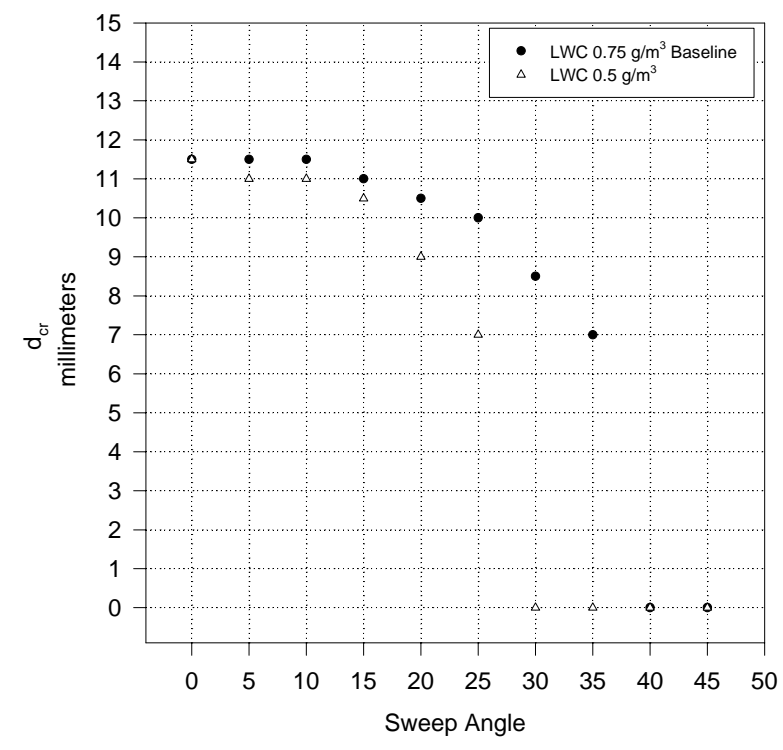

Figure 23. Change in critical distance with sweep angle for $L W C s$ of $0.75 \mathrm{~g} / \mathrm{m}^{3}$ and $0.5 \mathrm{~g} / \mathrm{m}^{3} . \Lambda=0^{\circ}$ to $45^{\circ}$ at $5^{\circ}$ increments, $\mathrm{V}=150 \mathrm{mph}, \mathrm{T}=25^{\circ} \mathrm{F}, \mathrm{MVD}=20 \mu \mathrm{m}$, $\tau=5 \mathrm{~min}$. From Vargas and Reshotko ${ }^{17}$ (1999).

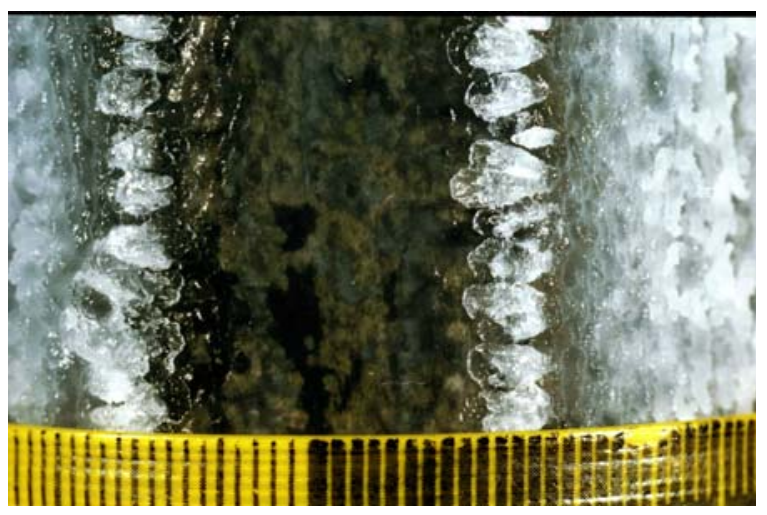

Figure 25. Glaze ice feather formation on an unswept cylinder. $\Lambda=0^{\circ}, V=200 \mathrm{mph}, T_{\text {total }}=12^{\circ} \mathrm{F}$, $L W C=0.75 \mathrm{~g} / \mathrm{m}^{3}, \mathrm{MVD}=20 \mu \mathrm{m}, \tau=1.5 \mathrm{~min}$. Smallest scale on the tape is $1 \mathrm{~mm}$.

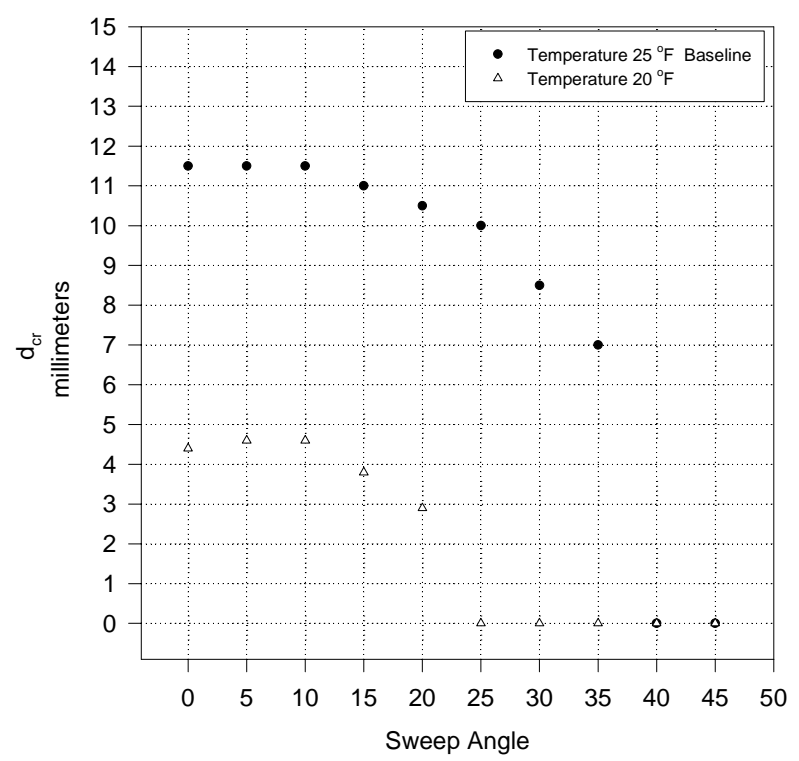

Figure 24. Change in critical distance with sweep angle at temperatures of $20^{\circ} \mathrm{F}$ and $25^{\circ} \mathrm{F} . \quad \Lambda=0^{\circ}$ to $45^{\circ}$ at $5^{\circ}$ increments, $\mathrm{V}=150 \mathrm{mph}, \mathrm{LWC}=0.75 \mathrm{~g} / \mathrm{m}^{3}, \mathrm{MVD}=20 \mu \mathrm{m}$, $\tau=5 \mathrm{~min}$. From Vargas and Reshotko ${ }^{17}$ (1999).

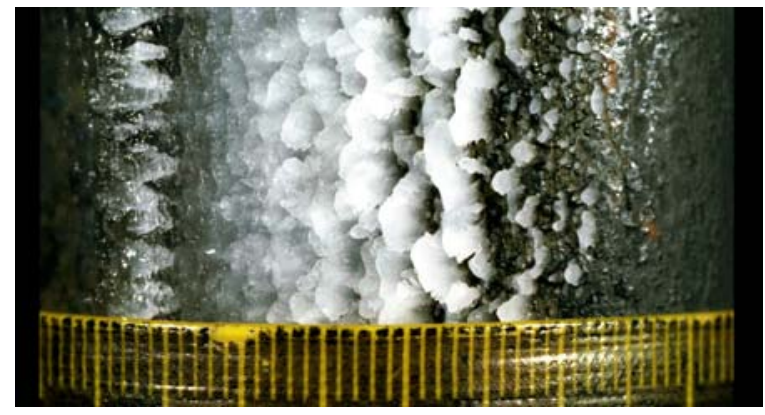

Figure 26. Rime ice feather formation on an unswept cylinder. $\Lambda=0^{0}, V=200 \mathrm{mph}, T_{\text {total }}=12^{\circ} \mathrm{F}$, LWC $=0.75 \mathrm{~g} / \mathrm{m}^{3}, \mathrm{MVD}=20 \mu \mathrm{m}, \tau=1.5 \mathrm{~min}$. Smallest scale on the tape is $1 \mathrm{~mm}$. 


\section{(a) Initiation Step}

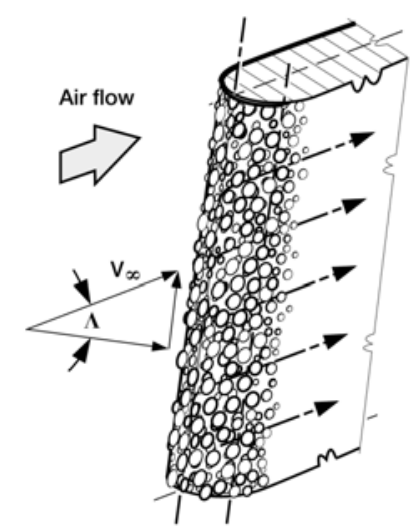

Roughness elements develop on the leading edge

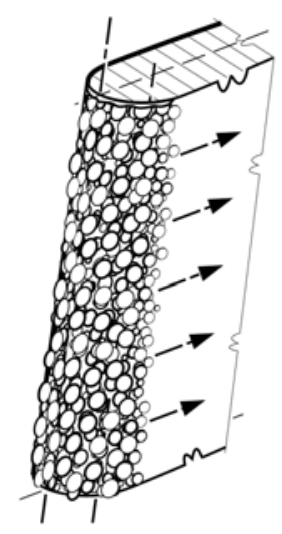

Roughness elements grow in size

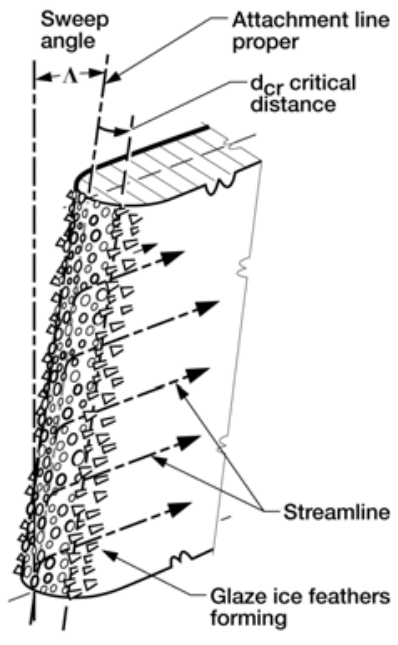

Roughness elements at a given distance from the attachment line develop into glaze ice feathers

\section{(b) Macroscopic Growth Step}

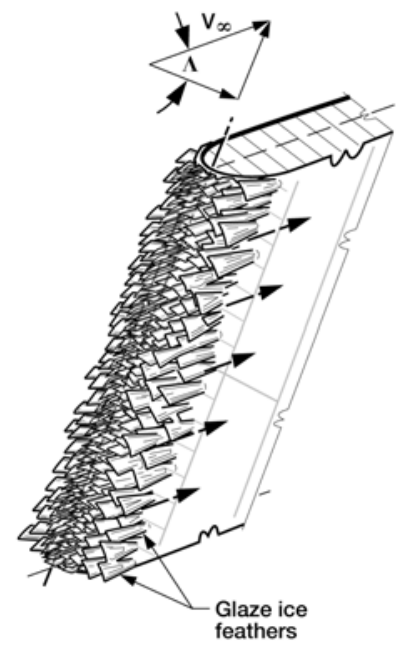

As the feathers grow, they develop a preferred direction of growth that is aligned perpendicular to the streamlines direction. The feathers growth is inclined at a given angle with respect to the leading edge surface. The feathers growth is at a given rate

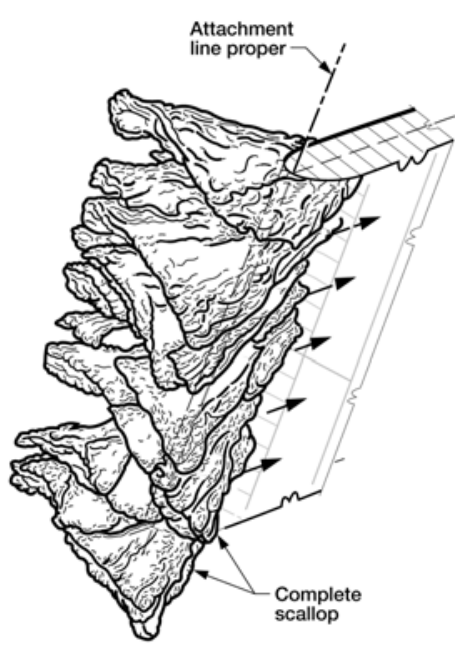

The feathers join along the preferred direction of growth to form ridges. The ridges join to form scallop tips

Figure 27. Conceptual Steps in the Modeling of Scallops. (a) Initiation Step (b) Macroscopic Growth Step. From Vargas and Reshotko ${ }^{18}$ (2000). 


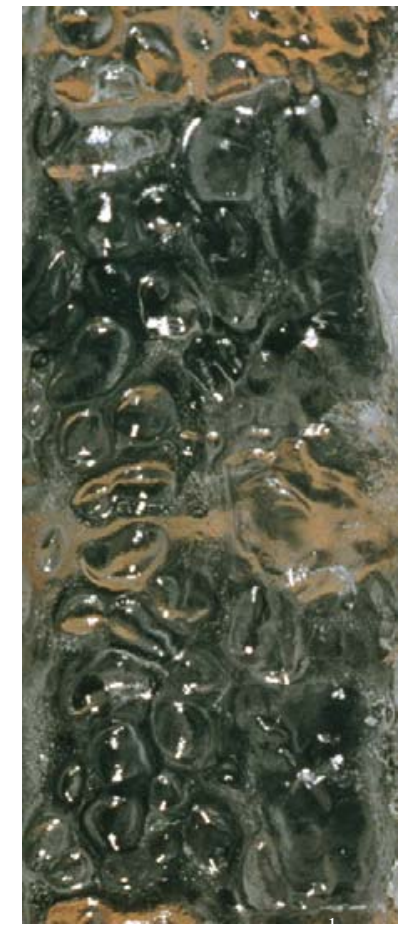

Figure 28. Roughness Elements, In-Flight Experiment, Airfoil: NACA 0012 Swept Wing Tip. $\Lambda=15^{\circ}, \quad V=143 \mathrm{mph}, \mathrm{T}_{\text {total }}=20.5^{\circ} \mathrm{F}$, $\mathrm{T}_{\text {static }}=16.7^{\circ} \mathrm{F} \mathrm{LWC}=0.51 \mathrm{~g} / \mathrm{m}^{3}, \mathrm{MVD}=12.6 \mu \mathrm{m}$, $\tau=10 \mathrm{~min}$. Direction of flow is from bottom to top. $1 \mathrm{~mm}$ separation is indicated at the lower right corner of the picture. From Vargas et al. $^{19}$ (1999), close-up and enlargement of Figure 27.

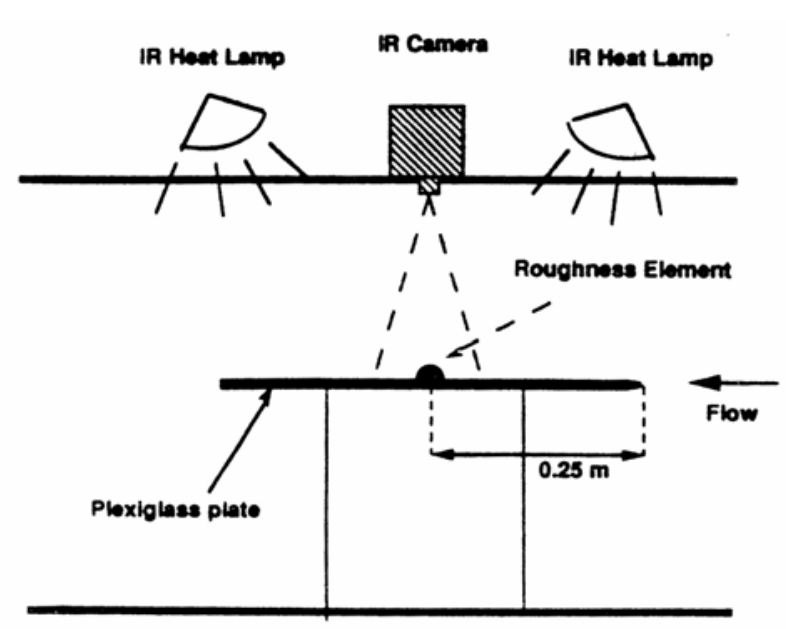

Figure 30a. Schematic View of Experimental Setup used by Henry et al. ${ }^{43}$ (1995).

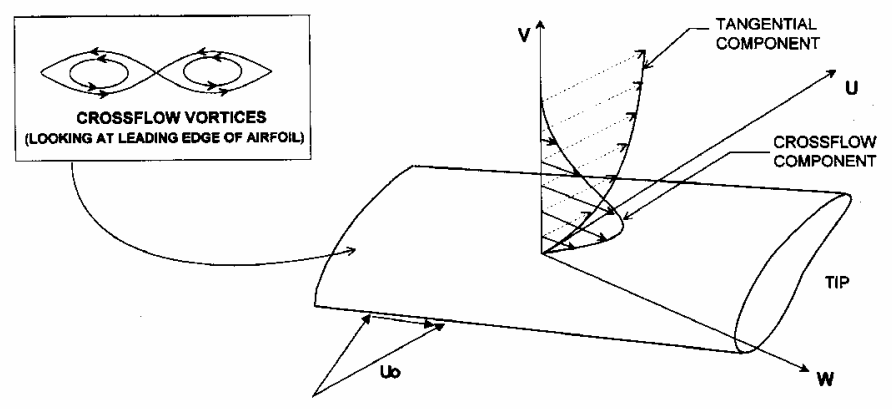

Figure 29. Cross Flow and Cross Flow Vortices. From Vargas and Reshotko $^{15,16}$ (1998).

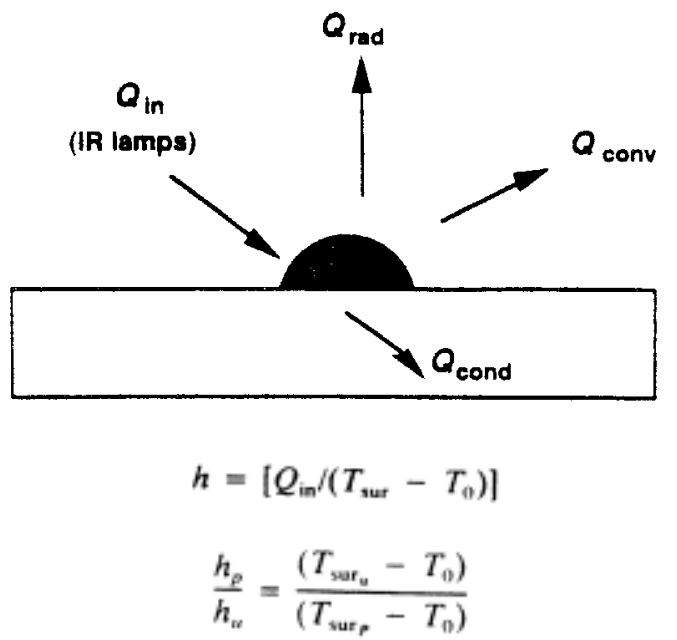

Figure 30b. Energy balance on a roughness element, as defined by Henry et al. ${ }^{45}$ (1995). 


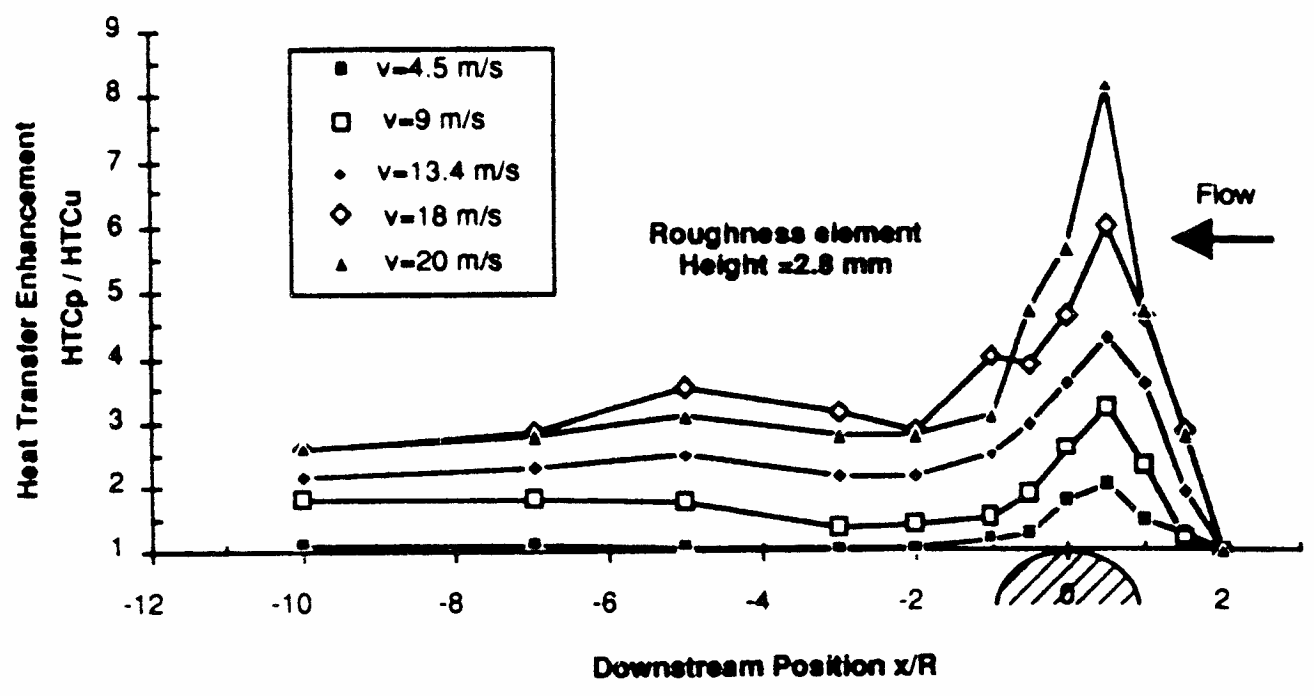

Figure 31. Heat transfer coefficient enhancement profile on a 2.8-mm-high roughness element in a laminar boundary layer. From Henry et al. ${ }^{43}$ (1995).

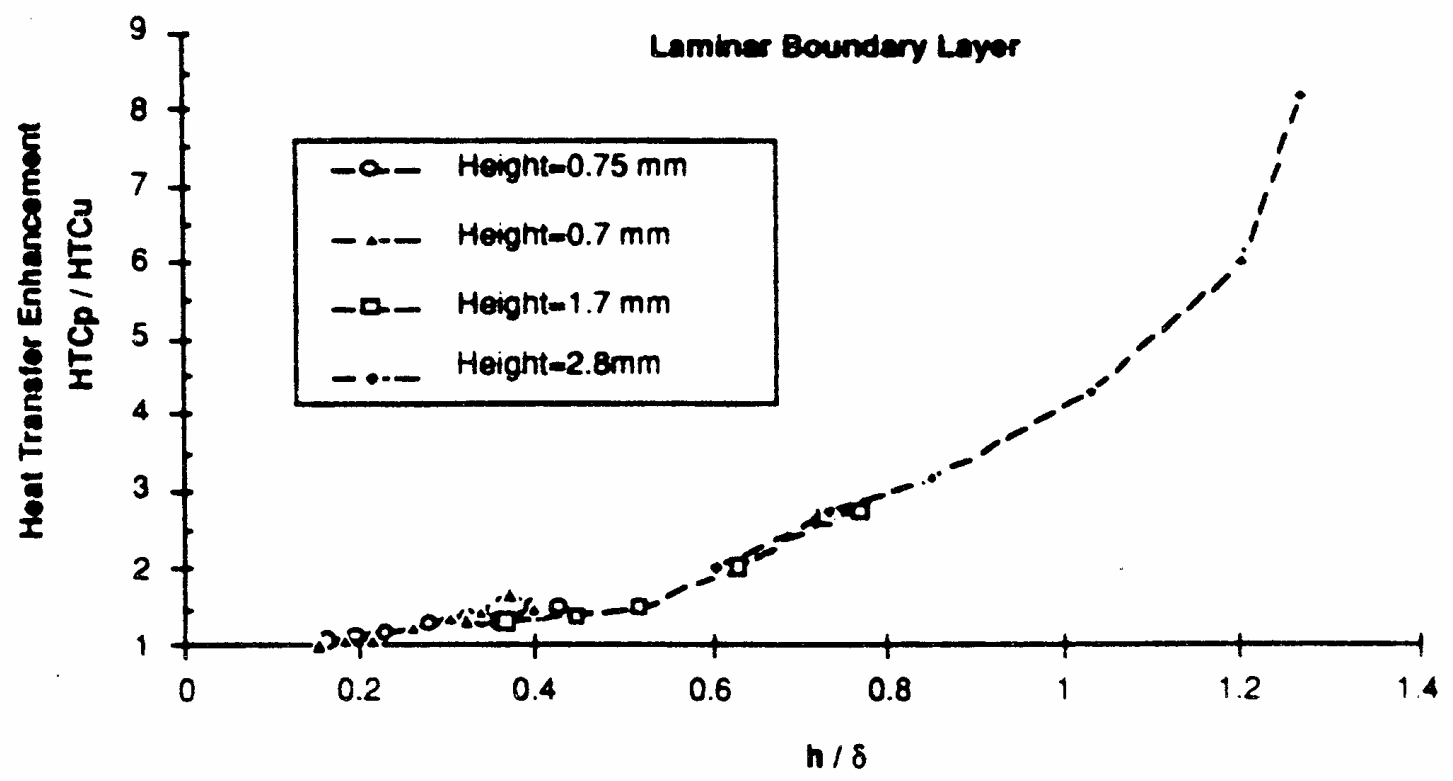

Figure 32. Maximum Heat Transfer Coefficient Enhancement vs Ratio of Height of Element to the Theoretical Laminar Boundary-Layer Thickness. From Henry et al. ${ }^{43}(1995)$. 

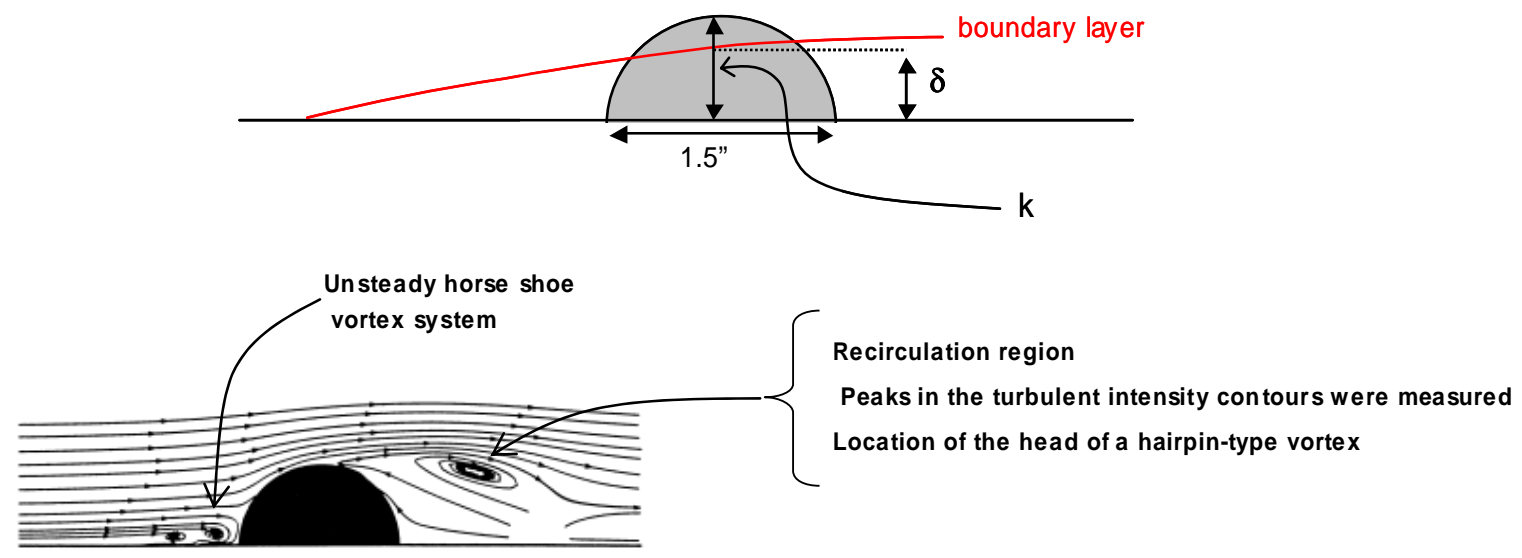

Figure 33. Flow field over single roughness element. From Winkler ${ }^{41}$ (1996).

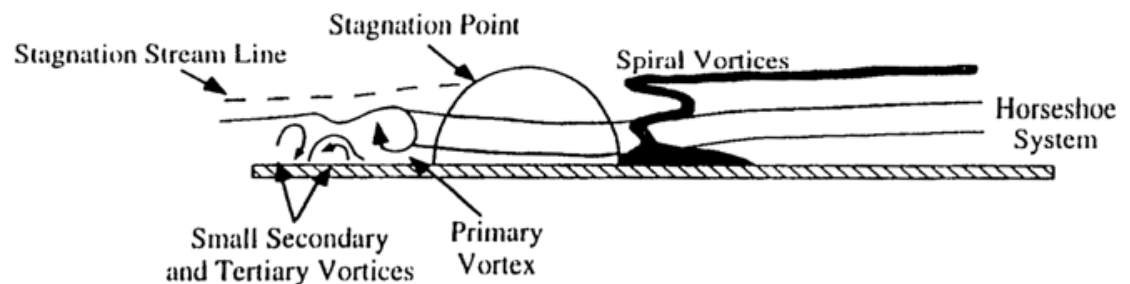

(a) Side View

Horseshoe Vortex

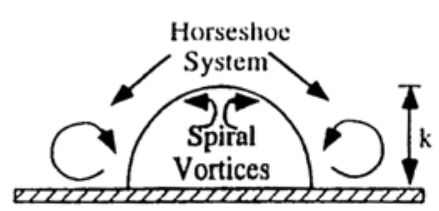

Rear Separation Pocket

(b) Rear View

- $\operatorname{Re}_{\mathrm{k}} \approx 300$

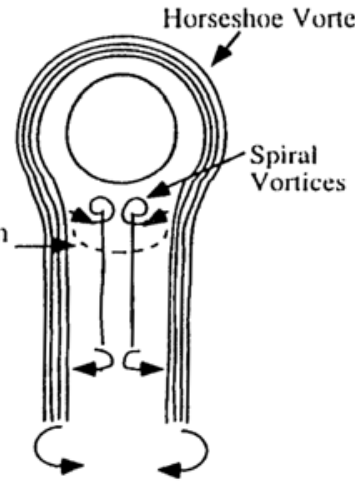

(c) Top View

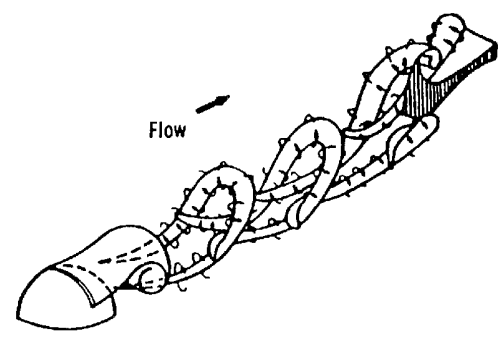

- $\mathrm{Re}_{\mathrm{k}}=350$ - 450

Figure 34. Flowfield about an Isolated Hemisphere. From Kerho ${ }^{39}$ (1995). 


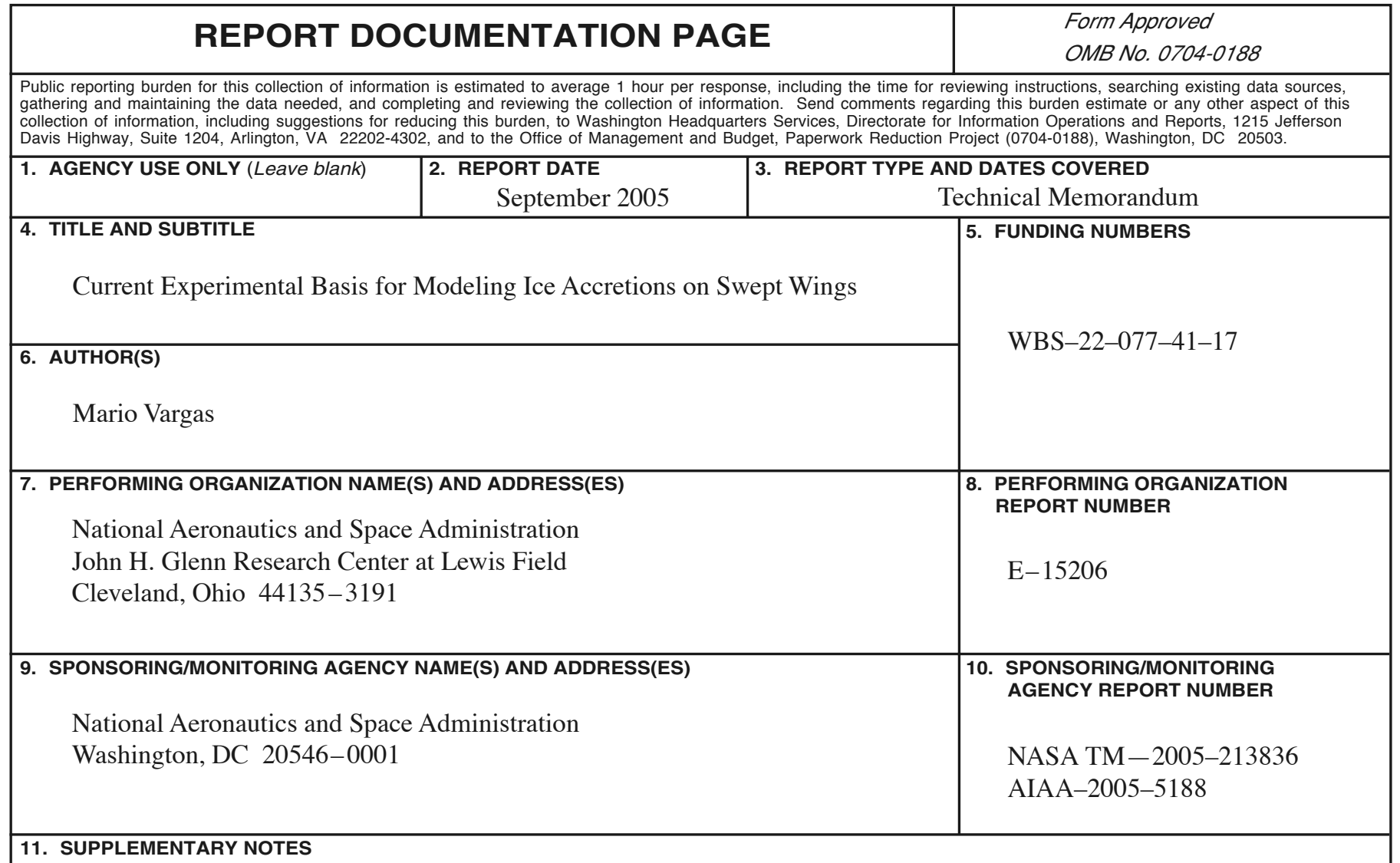

Prepared for the Fourth Theoretical Fluid Mechanics Meeting sponsored by the American Institute of Aeronautics and Astronautics, Toronto, Ontario, Canada, June 6-9, 2005. Responsible person, Mario Vargas, organization code RTI, 216-433-3943.

\begin{tabular}{|l|l|l|l|l}
\hline 12a. DISTRIBUTION/AVAILABILITY STATEMENT DISTRIBUTION CODE & 12b.
\end{tabular}

Unclassified - Unlimited

Subject Categories: 01, 03, and 34

Available electronically at http://gltrs.grc.nasa.gov

This publication is available from the NASA Center for AeroSpace Information, 301-621-0390.

\section{ABSTRACT (Maximum 200 words)}

This work presents a review of the experimental basis for modeling ice accretions on swept wings. Experimental work related to ice accretion physics on swept wings conducted between 1954 and 2004 is reviewed. Proposed models or explanations of scallop formations are singled out and discussed. Special emphasis is placed on reviewing the work done to determine the basic macroscopic mechanisms of scallop formation. The role of feather growth and its connection to scallop growth is discussed. Conceptual steps in modeling scallop formations are presented. Research elements needed for modeling are discussed.

\begin{tabular}{|c|c|c|c|}
\hline \multirow{2}{*}{\multicolumn{3}{|c|}{ Ice accretions; Swept wings; Scallop formations }} & $\begin{array}{l}\text { 15. NUMBER OF PAGES } \\
34\end{array}$ \\
\hline & & & 16. PRICE CODE \\
\hline $\begin{array}{l}\text { 17. SECURITY CLASSIFICATION } \\
\text { OF REPORT } \\
\text { Unclassified }\end{array}$ & $\begin{array}{l}\text { 18. SECURITY CLASSIFICATION } \\
\text { OF THIS PAGE } \\
\text { Unclassified }\end{array}$ & $\begin{array}{l}\text { 19. SECURITY CLASSIFICATION } \\
\text { OF ABSTRACT } \\
\text { Unclassified }\end{array}$ & 20. LIMITATION OF ABSTRACT \\
\hline NSN 7540-01-280-5500 & & & $\begin{array}{l}\text { andard Form } 298 \text { (Rev. 2-89) } \\
\text { scribed by ANSI Std. Z39-18 } \\
3-102\end{array}$ \\
\hline
\end{tabular}



